\title{
Use of 3D printing in head and neck surgery
}

\author{
Zastosowanie druku 3D w chirurgii głowy i szyi \\ Wirginia Likus $^{1}$ (D), Konstantinos Nechoritis ${ }^{*}$ (D), Aleksandra Różycka-Nechoritis** (D), Renata Wilk' (D), \\ Andrzej Hudecki (D), Wojciech Gaweł’ Katarzyna Przytuła-Kandzia4 (D), Jarosław Markowskił \\ ${ }^{1}$ Department of Anatomy, Faculty of Health Sciences in Katowice, Medical University of Silesia in Katowice, Poland \\ ${ }^{2}$ Institute of Non-Ferrous Metals, Gliwice \\ ${ }^{3}$ Solveere Sp. z 0.0., Ogrodzieniec \\ ${ }^{4}$ Department of Laryngology, Faculty of Medical Sciences in Katowice, Medical University of Silesia in Katowice, Poland \\ *Zatrudnienie w momemcie wysłania pracy do druku
}

\section{ABSTRACT}

Currently, 3D printing in medicine does not comprise only prostheses or implants, but also medical modelling and surgical planning. The future of 3D printing is printing combined with tissue bioengineering (bioprinting). Scaffolds made in $3 \mathrm{D}$ technology containing living cells are a step to creating tissues and organs. Three-dimensional printing in surgery is now considered the future of reconstructive and regenerative medicine. Head and neck surgery also benefits from advances in 3D printing. In this article, we will describe some of the possibilities offered by 3D printing in the aspect of education, training, and printed prostheses for the needs of head and neck surgery.

\section{KEY WORDS}

3D printing, otolaryngology, head and neck, surgery, education, reconstruction

\section{STRESZCZENIE}

Obecnie druk 3D w medycynie oznacza nie tylko protezy czy implanty, ale także modelowanie medyczne i planowanie chirurgiczne. Przyszłością będzie druk 3D połączony z bioinżynierią tkankową (bioprinting). Rusztowania wykonane w technologii 3D zawierające żywe komórki są krokiem do tworzenia tkanek i narządów. Druk trójwymiarowy w chirurgii uważany jest obecnie za przyszłość medycyny rekonstrukcyjnej i regeneracyjnej, a z dokonań na tym polu korzysta także chirurgia głowy i szyi. W prezentowanym artykule opiszemy niektóre możliwości, jakie daje druk 3D w aspekcie edukacji, szkoleń oraz drukowanych protez na potrzeby chirurgii głowy i szyi.

\section{SŁOWA KLUCZOWE}

druk 3D, otolaryngologia, głowa i szyja, chirurgia, edukacja, rekonstrukcje 


\section{INTRODUCTION}

The technology of 3D printing like, called additive manufacturing or rapid prototyping, already has a long and interesting history. The first reports on 3D printing technology come from the work of Hideo Kodama from the Nagoya Municipal Industrial Research Institute in 1981 [1,2], who developed the basics of the 3D printing process. In 1986, Charles Hull patented the stereolithographic 3D printing process and introduced 3D printers to the commercial market [3]. Since then, an expansion of 3D printing can be observed in many branches of the economy. Currently, medicine is considered the largest beneficent of 3D printing.

Various materials are used in 3D printing like, among others, titanium, plastic, natural and synthetic polymers such as PLA (polylactide), ABS (acrylonitrile butadiene styrene), photopolymers [4] and bioink. The actual 3D printing process can vary, depending on the properties of the starting material used for printing. The first patented method was stereolithography [2]. The principle of its operation is curing 2D layers of resin material with ultraviolet light. An advantage of this method is the possibility of receiving very precise shapes, while the price of photopolymers is its disadvantage [4]. FDM (fused deposition modelling) technology uses thermoplastic in filament form as the starting material, which melts when it passes through the nozzle and in liquid form it is applied on the table surface. In FDM technology, the "building" of a three-dimensional object consists in applying subsequent layers of thermoplastic. Nonetheless, before the next layer is applied, the previous one needs to solidify (cool). SLS/SLM (selective laser sintering/selective laser melting) is a $3 \mathrm{D}$ printing technology based on sintering metallic powders with a laser. In this technology, powder grains are applied to the worktable surface with a roller. Next, a laser gun generates an energy beam, which sinters spherical powder grains selectively or melts them locally. When using SLM technology, one can create objects of a much higher density than when using SLS technology. The advantage of this method is that it does not require any additional elements to stabilize the structure. The support material is unsintered powder, which can be reused in the process. The printing process itself is systematically improved and presently various types of printers can be distinguished on the market. According to the printing system, there are printers based on the following technologies: SLS/SLM, FDM, 3DP, stereolithography, or biplotters $[2,4]$. The materials used in $3 \mathrm{D}$ printing such as plastics (polycarbonate, polyamide, polylactide), waxes, metals (titanium) or photopolymers, are presently defined as standard materials.

Another type of printing is inkjet printing, in which the printer head deposits small droplets of raw material layer upon layer, creating a 3D object. These droplets can be obtained by various techniques such as piezoelectric, thermal, or electromagnetic methods [4]. The models are made relatively fast and at a low cost, but they are not as durable as those made with SLS technology. Due

\section{WPROWADZENIE}

Technologia druku 3D, zwana technologią przyrostową (additive manufacturing - AM) lub szybkim prototypowaniem, posiada już długą i ciekawą historię. Pierwsze doniesienia pochodzą z pracy Hideo Kodama z Miejskiego Instytutu Badań Przemysłowych w Nagoi z 1981 r. [1,2], który opracował podstawy procesu druku 3D. W 1986 r. Charles Hull opatentował proces druku 3D techniką stereolitografii i wprowadził drukarki 3D ma rynek komercyjny [3]. Od tego momentu obserwuje się ekspansję tej technologii w wielu gałęziach gospodarki, przy czym obecnie za największego jej beneficjenta uważa się medycynę.

W druku 3D wykorzystuje się różnorodne materiały, m.in. tytan, plastik, polimery naturalne i syntetyczne, takie jak: PLA (polilaktyd), ABS (akrylo-nitrylo-butadieno-styren), fotopolimery [4] oraz bioink. Właściwy proces drukowania 3D różni się w zależności od wyjściowego materiału stosowanego w druku. Pierwszą opatentowaną metodą była stereolitografia [2]. Zasadą jej działania jest utwardzanie światłem ultrafioletowym drukowanych z materiału żywicznego warstw 2D. Jako zaletę można wskazać otrzymywanie bardzo dokładnych kształtów, natomiast jako wadę - cenę fotopolimerów [4]. W technologii FDM (Fused Deposition Modelling) materiałem wyjściowym jest termoplast w postaci filamentu, który przechodząc przez dyszę, ulega stopieniu i w postaci płynnej zostaje nałożony na powierzchnię stolika. W technologii FDM „budowanie” trójwymiarowego obiektu polega na nakładaniu kolejnych warstw termoplastu, przy czym zanim kolejna warstwa zostanie naniesiona wcześniejsza musi ulec zestaleniu (ostygnięciu). Technologią druku 3D, polegającą na spiekaniu proszków metalicznych z zastosowaniem lasera, jest technologia SLS/SLM (Selective Laser Sintering/Selective Laser Melting). Ziarna proszku nanoszone są za pomocą wałka na powierzchnię stolika roboczego, a następnie działo laserowe generuje wiązkę energii, która w sposób selektywny spieka sferyczne ziarna proszku lub miejscowo je topi. Przy zastosowaniu technologii SLM powstają obiekty o znacznie większej gęstości, niż za pomocą technologii SLS. Zaletę tej metody stanowi brak potrzeby stosowania dodatkowych elementów stabilizujących konstrukcję, a materiałem podporowym jest niespieczony proszek, który można ponownie wykorzystać w procesie. Sam proces drukowania podlega systematycznemu udoskonalaniu. Obecnie na rynku wyróżnić możemy różne typy drukarek, które z uwagi na system opierają się na technologiach: SLS/SLM, FDM, 3DP, stereolitografii czy biploterach $[2,4]$. Wykorzystywane w druku 3D materiały, takie jak: tworzywa sztuczne (poliwęglan, poliamid, polilaktyd), woski, metale (tytan) czy fotopolimery, są w chwili obecnej definiowane jako materiały standardowe.

Innym typem jest druk atramentowy, gdzie głowica drukarki osadza małe kropelki surowca warstwa po warstwie, tworząc przedmiot 3D. Kropelki te można uzyskać różnymi technikami, takimi jak: metody piezoelektryczne, termiczne lub elektromagnetyczne [4]. 
to the very high quality of printing this method provides the possibility of using living cells as "ink material" and this technique is applied in "bioprinting", which is used in regenerative medicine in attempts to produce tissues and even organs. Printers using materials such as bioink or tissue spheroids are new in this area. Bioink is a water-based liquid [5], consisting of proteins such as collagen, gelatine, alginates, chitosan [6], enzymes [7] and cells suspended in a nutrient or saline solution [8]. The bioinks available on the market have different properties, depending on their composition: osteoinductive, angiogenic, chondrogenic, imitating natural ECM. After printing, the cells are supported by a neutral gel and the geometry of the printing is maintained as the cell model matures [9]. With a high precision, the printer puts subsequent cell layers, placed singularly or as aggregates on a gel substrate. Then, during cell differentiation into tissues, the biodegradable hydrogel diminishes [10]. Bioprinting has an advantage in producing scaffolds used in tissue engineering due to its fast production and a high precision of printing [11].

However, 3D bioprinting processes are limited to scaffolds supporting cells and simple body parts such as bones. Currently, the majority of the inks for 3D bioprinting is limited to collagen, gelatin, fibrin, ceramics, thermoplastics, or light-cured composites [11]. Nonetheless, this method is still at the stage of intense research because it encountered significant difficulties in proper vascularization of the tissues made of those materials. Currently, 3D bioprinting is used in prostheses and bone implants as they can be adjusted to the exact shape of the patient's body defect. Scientists are also working on using bioprinting for printing veins and arteries. The ultimate goal in tissue engineering and regenerative medicine is the direct production of organs by means of $3 \mathrm{D}$ bioprinting technology, i.e. printing a complete organ which can be directly transplanted into the human body $[12,13,14,15,16,17]$. Currently, intensive research is underway, among others in bioprinting neoplastic tumours. Thanks to this, it will be possible to model, to some extent, the natural structure of the tumour and treat it with, e.g. chemotherapeutic agents [18].

How can a model be printed for medical purposes? The data for model printing are obtained from CT scans, MRI, ultrasound, or a non-contact scanner [4]. Digital printing technology requires a representation of the geometric data obtained from these tests in STL or other formats [19]. They are used to make 3D objects from computer-aided designs (CAD). The development of polymer technology and, above all, the continuous improvement of 3D printing methods enables the development of materials printed in sterile conditions, which is important in the case of surgical procedures.

Before the output data is converted into the STL format, i.e. the format that allows printing of a virtual object, they are subjected to computer processing using CAD software, for example Materialise Mimics or 3D doctor. A CT scanner allows the mapping of a three-dimensio-
Modele tworzone są relatywnie szybko i tanio, jednak nie są tak trwałe, jak powstałe dzięki metodzie SLS. Bardzo wysoka rozdzielczość druku tą metodą i możliwość użycia jako „materiału tuszowego” żywych komórek, pozwala na zastosowanie tej techniki w „bioprintingu", który jest wykorzystywany w medycynie regeneracyjnej przy próbach produkcji tkanek a nawet narządów. Nowością w tym obszarze są drukarki stosujące takie materiały, jak bioink czy sferoidy tkankowe. Bioink jest cieczą na bazie wody [5], składającą się z białek typu kolagen, żelatyna, alginiany, chitozan [6], enzymów [7] i komórek zawieszonych w pożywce lub roztworze soli [8]. Dostępne na rynku bioinki mają różne cechy w zależności od składu: osteoindukcyjny, angiogenny, chondrogenny, naśladujący naturalny ECM. Po wydrukowaniu komórki są wspierane przez obojętny żel, a geometria wydruku jest utrzymywana w miarę dojrzewania modelu komórkowego [9]. Drukarka z dużą precyzją nanosi kolejne warstwy komórek pojedynczo lub w postaci agregatów na żelowe podłoże. Podczas różnicowania się komórek w tkanki biodegradowalny hydrożel zanika [10]. Bioprinting ma przewagę w produkcji rusztowań do zastosowań w inżynierii tkankowej, ze względu na szybkie wytwarzanie oraz wysoką precyzję wydruku [11].

Procesy bioprintingu 3D są jednak ograniczone do rusztowań wspierających komórki i prostych części ciała, takich jak kości. Obecnie większość biotuszy do bioprintingu 3D jest ograniczona do kolagenu, żelatyny, fibryny, ceramiki, tworzyw termoplastycznych lub kompozytów utwardzanych światłem [11]. Metoda ta pozostaje wciąż na etapie intensywnych badań, ponieważ wystąpiły duże trudności z odpowiednim unaczynieniem tkanek wykonanych $\mathrm{z}$ tych materiałów. Bioprinting 3D jest obecnie stosowany w protezach i implantach kostnych, ponieważ można je dopasować do prawidłowego kształtu ubytku ciała pacjenta. Naukowcy pracują także nad wykorzystaniem biodruku do drukowania żył i tętnic. Ostatecznym celem w inżynierii tkankowej i medycynie regeneracyjnej jest bezpośrednia produkcja narządów za pomocą technologii bioprintingu $3 \mathrm{D}$, tj. wydrukowania kompletnego organu, który może być bezpośrednio przeszczepiony do organizmu człowieka $[12,13,14,15,16,17]$. Obecnie trwają intensywne badania m.in. nad biodrukiem guzów nowotworowych. Dzięki temu będzie można w pewnym stopniu odwzorować naturalną strukturę guza i poddać go działaniu np. chemioterapeutyków [18].

W jaki sposób wydrukować model na potrzeby medyczne? Dane do wydruku uzyskuje się z tomografii komputerowej, rezonansu magnetycznego, USG czy skanera bezdotykowego [4]. Technologia druku wymaga cyfrowej reprezentacji uzyskanych w tych badaniach danych geometrycznych w formacie STL lub innych [19]. Wykorzystuje się je do tworzenia obiektów 3D $\mathrm{z}$ projektów wspomaganych komputerowo (CAD). Rozwój technologii polimerów, a przede wszystkim ciągłe udoskonalanie metod druku 3D, pozwala na 
nal model of the human body. Nevertheless, in order to obtain an image directly from the scanner that could be printed in 3D technology, it should be first converted into a format understood by a $3 \mathrm{D}$ printer. A universal extension used in 3D printing is STL. The process of obtaining such a ready-to-print file involves several stages:

1. The first step is to extract the tissue of interest from the CT image. It can be bone tissue, but also skin, blood vessels, or adipose tissue. Each tissue has a different density and most software for opening DICOM files present them in the form of graphic cross-sections. Therefore, the result of isolating a specific tissue is a two-dimensional bitmap, consisting of thousands - hundreds of thousands of cross-sections. These cross-sections, when put one on top of the other, create a 3D image.

2. The second stage is to create the so-called "model outlines." Using the bitmap, the software outlines and closes the outer edges of each cross-section, thus creating the contour and interior for a given layer.

3. The third stage consists in putting the subsequent layers onto each other to create the "outer shell" of the model and to build its internal structures.

4. Once the model has been assembled into a whole, the obtained "shell" shall be converted by placing a mesh of triangles on its outer surfaces. The more triangles, the more precise our 3D model will be. The finished mesh can then be saved in a format understandable to printers, i.e. STL.

5. Before starting the printing process, it must be ensured that the obtained model is a closed figure. There is special verification software used for that purpose. An algorithm examines the model and checks whether there any unclosed surfaces. Eventual defects are automatically fixed. At this stage, the density of the mesh of triangles obtained in the previous stage can also be optimized. Too high a density of the mesh may result in an artificially high weight (calculated in $\mathrm{Mb}$ ) of the 3D model. Too low a density of the mesh will, in turn, result in poor quality of the print surface and an inaccurate reproduction of the model compared to the CT scan (Fig. 1).

$3 \mathrm{D}$ printing combined with tissue bioengineering is the future. Printing scaffolds containing living cells is the first step to creating tissues and organs. Three-dimensional printing is presently considered to be the future of reconstructive and regenerative medicine. In this paper, some of the possibilities that 3D printing provides in the aspects of education, training and prostheses for neck and head surgery purposes will be described. opracowanie materiałów drukowanych w sterylnych warunkach, co jest istotne w przypadku zabiegów chirurgicznych.

Zanim wyjściowe dane zostaną przekształcone do formatu STL, czyli umożliwiającego wydrukowanie wirtualnego obiektu, są poddawane obróbce komputerowej z zastosowaniem oprogramowania CAD, takiego jak np. Materialise Mimics czy 3D doctor. Tomograf komputerowy pozwala na odtworzenie trójwymiarowego modelu ludzkiego ciała. Aby jednak obraz uzyskiwany bezpośrednio z tomografu nadawał się do druku 3D, należy najpierw przekonwertować go do formatu zrozumiałego dla drukarki 3D. Uniwersalnym rozszerzeniem, jakie stosuje się w druku 3D, jest STL. Proces otrzymania gotowego pliku obejmuje kilka etapów:

1. Pierwszym krokiem jest wyodrębnienie z obrazu TK tkanki, która nas interesuje. Mogą to być: tkanka kostna, ale także skóra, naczynia krwionośne, tkanka tłuszczowa. Każda tkanka posiada inną gęstość, a większość programów służących do otwierania plików DICOM przedstawia je w formie graficznych przekrojów. Efektem wyodrębnienia konkretnej tkanki jest zatem dwuwymiarowa mapa bitowa, składająca się z tysięcy-setek tysięcy przekrojów. Przekroje te, po nałożeniu jeden na drugi, tworzą obraz 3D.

2. Kolejnym etapem jest stworzenie tzw. obrysów modelu. Posługując się bitmapą, program obrysowuje i domyka krawędzie zewnętrzne każdego przekroju, tworząc w ten sposób kontur oraz wnętrze dla danej warstwy.

3. Trzeci etap polega na nałożeniu na siebie kolejnych warstw w celu stworzenia, ,skorupy zewnętrznej” modelu oraz zbudowania ich struktur wewnętrznych.

4. Po złożeniu modelu w całość należy przekonwertować otrzymaną ,skorupę”, poprzez naniesienie na jej zewnętrzne powierzchnie siatki trójkątów. Im większa liczba trójkątów, tym dokładniejszy będzie nasz model 3D. Gotową siatkę możemy następnie zapisać $\mathrm{w}$ formacie zrozumiałym dla drukarek, czyli STL.

5. Zanim rozpocznie się proces wydruku, należy jeszcze upewnić się, że uzyskany model jest zamkniętą bryłą. W tym celu używa się specjalnych programów weryfikacyjnych. Algorytm bada model i sprawdza, czy nie posiada on niedomkniętych płaszczyzn. Ewentualne niedoskonałości są automatycznie naprawiane. Na tym etapie możemy także zoptymalizować gęstość siatki trójkątów, uzyskanej na poprzednim etapie. Zbyt gęsta siatka może sztucznie zawyżać wagę (liczoną w $\mathrm{Mb}$ ) modelu 3D, natomiast zbyt rzadka będzie skutkowała niską jakością 


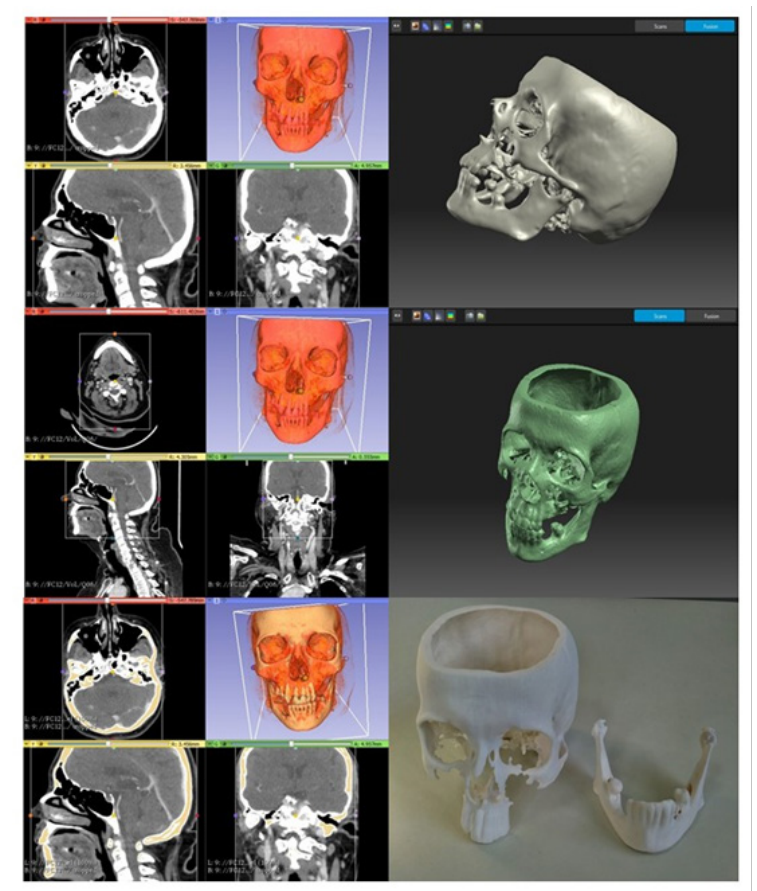

Fig. 1. Example of creating personalized implant - print made by Solveere from CT images of a patient.

Ryc. 1. Przykład tworzenia spersonalizowanego implantu - druk wykonany przez firmę Solveere z obrazów TK pacjenta.

\section{Use of 3D printing technology in head and neck surgery}

\section{$3 D$ printing in education and training}

Today, simulation using models is one of the main methods of teaching and improving manual skills [20, 21]. Pre-operative three-dimensional models are also used, among others, in thoracic surgery and orthopaedics. Orthopaedists use the models to plan surgical procedures for complicated fractures, while thoracic surgeons use them to plan how to best surgically access tumours in the thoracic cage.

In order for the training to fulfil its task, the 3D printed models must to be of high quality and to the highest extent reflect not only the anatomy but also the mechanical properties of the simulated structure. Particularly noteworthy is the possibility of obtaining paediatric models and those of rare, untypical anatomical variants or pathologies [22]. Surgeon training is important due to the fact that after practising during workshops, the time of performing the surgery is shortened, and thus the duration of anaesthesia and expensive stay in the operating room [23]. Additionally, 3D models can be useful in teaching the anatomy of complex structures of the head and neck area such as the temporal bone or paranasal sinuses. Sander et al. created a multi-material model of paranasal sinuses to explain to patients more easily and precisely what their disease is and what treatment options are available to them [24]. The results of their work indicate that the patient's thorough understanding of the treatment plan, achieved thanks to the powierzchni wydruków oraz niedokładnym odwzorowaniem modelu $\mathrm{w}$ porównaniu ze skanem z TK (ryc. 1).

Przyszłością jest druk 3D połączony z bioinżynierią tkankową. Drukowane skafoldy zawierające żywe komórki stanowią krok do tworzenia tkanek i narządów. Druk trójwymiarowy w chirurgii uważany jest obecnie za przyszłość medycyny rekonstrukcyjnej i regeneracyjnej. W prezentowanym materiale zostaną opisane niektóre możliwości, jakie stwarza druk 3D w aspekcie edukacji, szkoleń oraz protez na potrzeby chirurgii głowy i szyi.

\section{Wykorzystanie technologii druku 3D w chirurgii glowy i szyi}

\section{Druk 3D w edukacji i szkoleniach}

Symulacja z użyciem modeli jest dziś jednym z podstawowych sposobów nauczania i doskonalenia umiejętności manualnych [20,21]. Przedoperacyjne trójwymiarowe modele wykorzystywane są także między innymi w torakochirurgii i ortopedii. Ortopedzi używają ich do planowania zabiegów operacyjnych skomplikowanych złamań, zaś torakochirurdzy do planowania najlepszego dojścia chirurgicznego w operacjach guzów klatki piersiowej.

Aby szkolenie spełniało swoje zadanie, wydrukowane w technologii 3D modele muszą być wysokiej jakości i jak najdokładniej odzwierciedlać nie tylko anatomię, lecz także właściwości mechaniczne symulowanej struktury. Na szczególną uwagę zasługuje możliwość uzyskania modeli pediatrycznych oraz o rzadkich, nietypowych wariantach anatomicznych lub patologiach [22]. Szkolenia chirurgów są ważne ze względu na fakt, iż po treningach skraca się czas zabiegu, a tym samym czas trwania znieczulenia i kosztownego pobytu na sali operacyjnej [23]. Modele 3D mogą być też użyteczne w nauczaniu anatomii skomplikowanych struktur okolicy głowy i szyi, takich jak kość skroniowa czy zatoki oboczne nosa. Sander i wsp. stworzyli wielomateriałowy model zatok obocznych nosa, aby łatwiej i dokładniej wytłumaczyć pacjentom, na czym polega ich choroba i jakie mają opcje leczenia [24]. Wyniki ich pracy wykazały, że dokładne zrozumienie przez pacjenta planu leczenia, dzięki pokazowi na modelu 3D, poprawiło ostateczne wyniki leczenia [24].

Podczas planowania operacji chirurgicznych lekarz, próbując lokalizować zmianę, bazuje przede wszystkim na badaniach obrazowych i ewentualnych rekonstrukcjach, co w niektórych przypadkach nie jest wystarczające. Stworzenie modeli 3D w skali 1:1 lub większej pozwala na zaplanowanie przez chirurga dokładnych procedur w czasie operacji, zwłaszcza w zabiegach rekonstrukcyjnych, gdzie istotne jest odtworzenie pożądanego kształtu czy symetrii. Pierwszy przeszczep twarzy w Polsce dokonany przez zespół chirurgów z Instytutu Onkologii w Gliwicach także był wspomagany modelami czaszki pochodzącymi z drukarki 3D. Modele te drukowano na bieżąco zarówno przed, jak i podczas operacji i służyły zespołowi chirurgów za 
demonstration on the $3 \mathrm{D}$ model, improved the final results of the treatment [24].

When planning surgical operations, in order to locate the lesion, the physician relies primarily on imaging examinations and alternatively, reconstructions. In some cases, that may not be sufficient. Creating 3D models in a 1:1 or larger scale allows the surgeon to plan detailed procedures for surgery, especially in reconstructive procedures, where it is important to reproduce the desired shape or recreate the symmetry. The first face transplant in Poland, performed by a team of surgeons of the Institute of Oncology in Gliwice, was supported by skull models from a 3D printer as well. These models were printed continuously, before and during the surgery and served the surgeons as a model to recreate the desired skull geometry of the patient with an extensive frontal skull trauma [25]. Already in 2015, physicians of the Voivodeship Hospital for Children in Bydgoszcz were the first in Poland to perform a laryngological surgery demonstration on a head model from a 3D printer. Temporal bone models were used to improve the methods of inserting cochlear implants in children [26].

The internal structure of the temporal bone is extremely complex. For years attempts have been made to create a model that would allow laryngologists to receive high-quality training on procedures in the temporal bone area, such as labyrinthectomy. Currently, the "gold standard" is training on bones from corpses. Paediatric temporal bones and bones with rare anomalies are very difficult to access [22]. Attempts to train on animal bones were unsuccessful because they significantly differ from the anatomy of human bones. Similarly, synthetic temporal bones made of plastics, ceramics or resin did not meet expectations due to their poor anatomical realism and little similarity in the mechanical properties of the used materials in relation to those of bones from a corpse [22].

The first model of a temporal bone for microsurgery that used 3D printing was made by Vorwerk and Begall in 1998. Using CT scans of temporal bones, anatomical preparations and CT scans of patients, they were able to reconstruct $3 \mathrm{D}$ images with a CAD workstation. In order to reproduce the anatomical features of the temporal bone as accurately as possible, the prints were made using the stereolithographic technique [22].

Using 3D printing, Monfared et al. created a surgical middle ear simulator (SMS) from two different materials simulating bone tissue and soft tissues. The simulator consisted of a box with the dimensions of an adult person's external auditory meatus and an internal inlay based on an otosclerosis model. The simulator was assessed by otologists from 6 academic centres. The SMS was judged to have exact dimensions by $83.3 \%$ of the respondents and $66.6 \%$ of them considered its tactile feedback to be precise. According to $78 \%$ of physicians, practicing stapedotomy with a simulator translates into improved surgery techniques. During such training, it is possible to see and "feel virtually" contact with a bone, but these simulators are not able to precisely recreate the pressure exerted on the bone, e.g. when drilling du- wzór, wspomagając odtworzenie docelowej geometrii czaszki pacjenta po rozległym urazie [25]. Bydgoscy lekarze z Wojewódzkiego Szpitala Dziecięcego jako pierwsi w Polsce już w 2015 r. przeprowadzili pokaz operacji laryngologicznej na modelu głowy z drukarki 3D. Wykorzystano modele kości skroniowych, aby doskonalić metody zakładania implantów ślimakowych u dzieci [26].

Budowa wewnętrzna kości skroniowej jest niezwykle skomplikowana. Od lat podejmowane są próby stworzenia modelu, który umożliwi laryngologom wysokiej jakości szkolenia $\mathrm{z}$ przeprowadzanych $\mathrm{w}$ obrębie kości skroniowej zabiegów, takich jak labiryntektomia. Obecnie ,złotym standardem” są szkolenia na kościach pochodzacych ze zwłok. Bardzo trudno dostępne są pediatryczne kości skroniowe i kości z rzadko występującymi anomaliami [22]. Próby treningu na kościach zwierzęcych nie były udane, ponieważ znacznie różnią się anatomią od ludzkich. Syntetyczne kości skroniowe wykonywane z tworzyw sztucznych, ceramiki i żywicy również nie spełniły oczekiwań, ze względu na słaby realizm anatomiczny oraz małe podobieństwo mechanicznego zachowania się użytych materiałów w stosunku do kości pochodzących ze zwłok [22].

Pierwszy model z wykorzystaniem druku 3D kości skroniowej dla mikrochirurgii został stworzony przez Vorwerk i Begall w 1998 r. Za pomocą tomografii komputerowej kości skroniowych preparatów anatomicznych i obrazów TK pacjentów udało im się zrekonstruować obrazy 3D na stacji roboczej CAD. Wydruki wykonano techniką stereolitografi, aby jak najdokładniej odtworzyć anatomiczne cechy kości skroniowej [22].

Monfared i wsp. za pomocą druku 3D stworzyli chirurgiczny symulator ucha środkowego (SMS) z dwóch różnych materiałów imitujących tkankę kostną i tkanki miękkie. Symulator składał się ze skrzynki o wymiarach zewnętrznego kanału słuchowego osoby dorosłej i wkładu wewnętrznego opartego na modelu otosklerozy. Symulator oceniali otolodzy z 6 ośrodków akademickich. 83,3\% uznało, że SMS ma dokładne wymiary, a $66,6 \%$ stwierdziło, że symulator ma dokładną dotykową informację zwrotną. Według 78\% lekarzy ćwiczenie stapedotomii z symulatorem przekłada się na poprawę techniki zabiegu. Podczas takiego treningu widzi się i „czuje wirtualnie” kontakt z kością, ale symulatory te nie są w stanie dokładnie odtworzyć siły nacisku wywieranego na kość na przykład podczas wiercenia w czasie operacji [27]. Bardzo dużym wyzwaniem dla druku 3D było wierne odtworzenie wewnętrznej struktury oraz mechanicznych właściwości kości. Trudności sprawiały artefakty powstałe po usunięciu konstrukcji wspierających model oraz utworzenie pustych przestrzeni powietrznych [27].

Ważnym udoskonaleniem było uzyskanie światła ślimaka, niezbędnego do treningu wszczepiania implantów ślimakowych [28]. W praktyce zastosowanie znalazł model kości skroniowej wytwarzany przez niemiecką formę Phacon. Dane do jego opracowania uzyskano przez skanowanie prawidłowych ludzkich kości skroniowych przy użyciu TK. Model stworzono, uży- 
ring surgery [27]. An enormous challenge for the printing was faithful reproduction of the internal structure and mechanical properties of a bone. Difficulties were caused by the artefacts arising after removing the structures supporting the model and creating empty spaces of air [27].

An important improvement was obtaining a cochlear lumen, which is essential for cochlear implant implantation training [28]. In practice, the model produced by the German Phacon company, was used. Data for its development were obtained by scanning normal human temporal bones using CT. The model was created employing a $3 \mathrm{D}$ printer using a powder and binding agent, adding colour, and removing cast powder from anatomically hollow structures. The tympanic membrane was replaced by a silicon sheet and the auditory ossicles were cast as one rigid structure. The facial nerve, sigmoid sinus and carotid artery were printed as empty channels, which were then filled with coloured wires [22].

De Cruz and Francis investigated the usefulness of temporal bones printed with the $3 \mathrm{D}$ technique from composite materials to serve as tools for preoperative training for residents. The residents performed such procedures as mastoidectomy, epitympanectomy, posterior tympanotomy and ossiculoplasty. After completing the training, the participants filled in a form consisting of questions answered on a five-point Likert scale, where a score of 3 meant at least acceptable and 5 at least an equivalent resemblance to real temporal bone. Everyone assessed the bone anatomical realism as comparable to corpse bones. In particular, the depth perception (4.7), anatomical precision (4.3) and tactile feedback (4.0) were assessed favourably. The assessment of drilling in a bone (3.7) and colour contrasts (3.2) were slightly worse. Model training itself was assessed as at least equal to training on corpses. Exercises on the lateral parts of the temporal bone model were assessed as especially useful; those on the medial parts were rated slightly worse. It was also noted that in comparison with using human bones from corpses, model training is useful not only for learning (score of 4.8) but it also facilitates the planning of surgical tasks (4.8), improves hand-eye coordination (4.8) and serves to improve surgery techniques (4.5). As a general training tool, the models were rated 4.7. Otolaryngologists training with the models found the synthetic temporal bones recommendable (4.8) and the acquired skills transferable to the operating room (4.3) because they improved confidence during surgery (4.7). Model training was considered worthy of including in the curriculum (4.7), however, the proposal to replace all training with 3D models was not so positively assessed (3.5) [22].

In the research of Hochman et al., based on an algorit$\mathrm{hm}$ a model in the form of layers was first developed and then assembled into a three-dimensional model of a temporal bone, with removal of the content from places of air space. With such prepared models otolaryngologists trained, whose earlier experience gained during training on corpses was sufficient to evaluate the artifi- wając drukarki 3D z zastosowaniem proszku i środka wiążącego, dodano kolor i usunięto odlany proszek ze struktur anatomicznie pustych. Błonę bębenkową zastąpiono arkuszem krzemowym, a kosteczki słuchowe zostały odlane w postaci jednej sztywnej struktury. Nerw twarzowy, zatokę esowatą i tętnicę szyjną wydrukowano jako puste kanały, które wypełniono kolorowymi drucikami [22].

De Cruz i Francis badali przydatność kości skroniowych wydrukowanych techniką 3D z materiałów kompozytowych, mających służyć za narzędzia do treningu przedopoeracyjnego dla rezydentów. Rezydenci wykonywali takie zabiegi, jak: mastoidectomia, epitympanektomia, tylna tympanotomia i ossikuloplastyka. Po ukończeniu ćwiczeń uczestnicy wypełniali formularz składający się z pytań, na które udzielano odpowiedzi w pięciostopniowej skali typu Likerta, gdzie wynik 3 oznaczał przynajmniej akceptowalne, a 5 przynajmniej równoważne podobieństwo do prawdziwej kości skroniowej. Realizm anatomiczny kości został przez wszystkich oceniony jako porównywalny z kośćmi zmarłych. W szczególności pozytywnie oceniono percepcję głębi $(4,7)$, dokładność anatomiczną $(4,3)$ i dotykowe sprzężenie zwrotne $(4,0)$. Nieco gorzej wypadła ocena wiercenia w kości $(3,7)$ i kontrasty barw $(3,2)$. Samo wykonywanie ćwiczeń na modelu zostało uznane za przynajmniej równoważne z ćwiczeniami na zwłokach. Szczególnie przydatne okazały się ćwiczenia na bocznych częściach modelu kości skroniowej, nieco gorzej na przyśrodkowych. Zauważono również, że w porównaniu z ludzkimi kośćmi ze zwłok, ćwiczenia na modelach są przydatne nie tylko do nauki (ocena 4,8), ale znacznie ułatwiają planowanie zadań chirurgicznych $(4,8)$, poprawiają koordynację ręka-oko $(4,8)$ oraz służą poprawie technik operacyjnych $(4,5)$. Jako ogólne narzędzie szkoleniowe modele oceniono na 4,7. Laryngolodzy ćwiczący na modelach stwierdzili, że syntetyczne kości skroniowe są godne polecenia $(4,8)$, a nabyte umiejętności można przenieść na blok operacyjny $(4,3)$, ponieważ poprawiały pewność siebie podczas zabiegu $(4,7)$, oraz rekomendowali ich włączenie do programu nauczania $(4,7)$, przy czym propozycje całkowitego zastąpienia szkoleń modelami 3D nie została aż tak pozytywnie ocenione $(3,5)$ [22].

W badaniach Hochman i wsp., opierając się na algorytmie, najpierw opracowywano model $\mathrm{w}$ postaci warstw, a następnie składano w trójwymiarowy model kości skroniowej z usunięciem zawartości w miejscach przestrzeni powietrznych. Na tak przygotowanych modelach ćwiczyli laryngolodzy, których wcześniejsze doświadczenia zdobyte podczas treningów na zwłokach były wystarczające do oceny sztucznych kości skroniowych. Oceniając ich przydatność, posłużono się 7-stopniową skalą Likerta, która obejmuje podobieństwo budowy anatomicznej, przydatność w rozwijaniu umiejętności operacyjnych, wartość edukacyjną. Wyniki wykazały, że fizyczne właściwości modelu 3D są dość podobne do kości, zwłaszcza w aspekcie wiercenia w ich obrębie. Budowa wewnętrzna była zadowalająca (zakres 4,9-6,2). Model uznano za korzystne narzędzie szkole- 
cial temporal bones. A 7-point Likert scale was used for assessment, which covers the similarity of anatomical structure, usefulness for developing surgical skills, and educational value. The results showed that the physical properties of the 3D model are quite similar to those of bones, especially in the aspect of drilling in bones. The internal structure was satisfactory (range 4.9-6.2). The model was considered a beneficial training tool for all kinds of mastoidectomy (range 5.9-6.6), posterior tympanotomy $(6.5 \pm 0.71)$. Training with the models printed in the $3 \mathrm{D}$ technique improves confidence $(6.7$ $\pm 0.68)$ and surgical efficiency $(6.7 \pm 0.48)$ [29]. The research by Rose et al. also confirmed that temporal bone models printed in 3D have a potential benefit in terms of surgical training, preoperative simulation in difficult otolaryngologic cases and standardised testing of surgical skills for temporal bone surgery. A multicoloured, multi-material temporal bone model printed in the incremental technique was used for the tests [30]. The Phacon company improved temporal bone models, and Mick et al. demonstrated that the models are suitable for training residents in their 1-3 years of specialisation, although the tympanic membrane, auditory ossicular chain mobility, facial nerve and colour contrasts need to be improved [31].

A good way to learn ear surgery with access through the external auditory canal (transcanal endoscopic ear surgery - TEES) can be training with simulators printed thanks to $3 \mathrm{D}$ technology, which ensure high faithfulness of anatomical structures. According to Nagendran et al., research on the use of box laparoscopic simulators for surgeons shows improvement in technical skills, especially in trainees with little experience in endoscopic ear surgery [32]. In the described study, the external auditory meatus of the simulator was designed according to anthropometric measurements and reproduced an anatomically consistent middle ear entry. A composite material was used to create the simulator, and it was printed by an inkjet printer using dye. The test area - the middle ear space, was designed in the shape of a dome. The auditory canal can be connected with the middle ear at any angle, and the dome shape provides the possibility for any access. The dome floor corresponded to the surface of the medial wall of the tympanic cavity space and was flat with two small grooves that enabled easy replacement of module test platforms. The auditory canal entered the middle ear space at a $45^{\circ}$ angle. On the front surface the dome was equipped with a movable door that enabled the exchange of module test platforms to switch the tasks of the simulator. The test was carried out using a 3D simulator, rigid endoscopes, and microsurgical equipment. The participants were surgeons, who were divided into two groups, depending on their level of experience. The simulator task was to move three rings from one peg to the other and back. To do that, forceps and an endoscope were used. The task consisted of three serial attempts with the dominant hand and three serial attempts with the non-dominant hand. After having completed the task, there were questions concerning the level of surgi- niowe w przypadku wszystkich rodzajów mastoidectomii (zakres 5,9-6,6) oraz tylnej tympanotomii $(6,5 \pm$ 0,71). Ćwiczenie na modelach drukowanych w technice 3D poprawia pewność $(6,7 \pm 0,68)$ i sprawność operacyjną $(6,7 \pm 0,48)$ [29]. Badania Rose i wsp. także potwierdziły ich potencjalną korzyść w zakresie szkolenia chirurgicznego, symulacji przedoperacyjnej w trudnych przypadkach laryngologicznych i standaryzowanego testowania umiejętności chirurgicznych dotyczących zabiegów wykonywanych na kości skroniowej. Do testów wykorzystali oni wielokolorowy, wielomateriałowy model kości skroniowej wydrukowany techniką przyrostową [30].

Firma Phacon udoskonaliła modele kości skroniowej, a Mick i wsp. wykazali, iż są one odpowiednie do szkolenia rezydentów na 1-3 roku specjalizacji, mimo że poprawy wymaga jednak błony bębenkowa i okrągła, ruchomość łańcucha kosteczek słuchowych, nerw twarzowy oraz kontrasty kolorów [31].

Dobrym sposobem do nauki chirurgii ucha $z$ dostępu przez przewód słuchowy zewnętrzny (transcanal endoscopic ear surgery - TEES) mogą być ćwiczenia na symulatorach wydrukowanych dzięki technice 3D, zapewniających wysoką wierność struktur anatomicznych. Według Nagendran i wsp. w badaniach nad wykorzystaniem pudełkowych laparoskopowych symulatorów dla chirurgów stwierdzono poprawę umiejętności technicznych osób, zwłaszcza stażystów mających niewielkie doświadczenie w operacjach endoskopowych ucha [32]. W opisywanym badaniu przewód słuchowy zewnętrzny-symulatora został zaprojektowany według pomiarów antropometrycznych i odtwarzał anatomicznie zgodne wejście do ucha środkowego. Do stworzenia symulatora wykorzystano materiał kompozytowy, a wydruk wykonano na drukarce atramentowej z użyciem barwnika. Obszar testowy przestrzeń ucha środkowego - został zaprojektowany w kształcie kopuły. Przewód słuchowy może łączyć się z uchem środkowym pod dowolnym kątem, a kształt kopuły zapewnia możliwość dowolnego dojścia. Podłoga kopuły odpowiadała powierzchni przyśrodkowej ściany jamy bębenkowej i była płaska $\mathrm{z}$ dwoma rowkami, które umożliwiały łatwą wymianę modułowych platform testowych. Przewód słuchowy wchodził do przestrzeni ucha środkowego pod kątem $45^{\circ}$. Kopuła na przedniej powierzchni posiadała ruchome drzwiczki umożliwiające wymianę modułowych platform testowych w celu przełączania zadań symulatora. Badanie przeprowadzono za pomocą symulatora 3D, sztywnych endoskopów i sprzętu mikrochirurgicznego. Uczestnikami byli lekarze chirurdzy, których podzielono na dwie grupy, w zależności od poziomu doświadczenia. Zadaniem symulatora było przeniesienie trzech obręczy z jednego kołka na drugi i z powrotem. W tym celu użyto kleszczyków i endoskopu. Zadanie obejmowało trzy seryjne próby ręką dominującą i trzy seryjne próby ręką niedominującą. Po wykonaniu zadania pytania dotyczyły doświadczenia chirurgicznego i oceny pracy z symulatorem. Wraz ze wzrostem liczby wykonywanych prób ulegał skróceniu średni czas ich wykony- 
cal experience and assessment of work with the simulator. The more attempts made, the shorter time needed to accomplish them. In the post-training questionnaire, all the participants stated that the practice provides the necessary experience to perform a real TEES procedure. The simulation also provided the participants with the necessary muscle memory to perform the actual procedure. The study had also some limitations because, according to the participants, the shape of the external auditory meatus was too "narrowing" due to the hardness of the materials it was made of. The inability to move within the cartilaginous part of the canal also caused some difficulties in handling the tools. The action performed during the simulation is only one of many necessary in TEES. On the other hand, the learning curve covers many of the actions constituting the surgery. Scientists are working to ensure that new versions of the TEES simulator are equipped with an ossicular chain, and an oval window could be designed for reconstructing auditory ossicles or stapes bone surgery [32]. Another problem that can be solved by a $3 \mathrm{D}$ printed model is training in the placement of a tracheoesophageal prosthesis (TEP). TEP enables voice generation after a total laryngectomy $[33,34,35,36,37,38]$. Surgery task training with simulators is aimed at improving technical skills and thus ensuring patient safety [39, $40,41]$. The development of $3 \mathrm{D}$ printing makes it possible to use inexpensive models to compliment such training $[42,43,44,45]$. The simulator was designed using Fusion360 CAD (Autodesk, San Rafael, California). The components were printed in $3 \mathrm{D}$ technology by a printer using polylactic acid (PLA); squid tissues simulated the common tracheoesophageal wall [46]. The study involved 10 residents ( 5 with less experience, 5 with more experience), who were first shown an instructional video on placing a TEP with explanations provided by an expert. The participants completed a questionnaire before and after the simulation. All the participants agreed that the skills acquired during the simulation will be useful during a real operation. The younger residents particularly benefited from the simulation. The elements printed in 3D technology were not damaged during repeated simulations and the use of squid tissues provided very realistic tactile feedback, similar to that of oesophageal mucosa without increasing the costs. An additional advantage of the models is their precision, with the possibility of achieving resolution up to 20 micrometres [46]. To sum up, three-dimensional TEP simulators provide the opportunity to train this complicated procedure. Thanks to their low production costs and high quality, they can be used on a large scale, which will significantly accelerate resident training and increase their skills in the operating room.

Endoscopic sinus surgery presents a significant surgical challenge due to its complexity and anatomical variability, as well as the risk of serious complications. Simulation models have proved to be effective in gaining endoscopic skills and training operational procedures. Research has shown that a simulator may be useful as wania. W kwestionariuszu wypełnianym po treningu wszyscy uczestnicy stwierdzili, że ćwiczenie dostarcza doświadczenia niezbędnego podczas wykonywania prawdziwej procedury TEES. Symulacja zapewniła również trenującym pamięć mięśniową niezbędną do przeprowadzenia rzeczywistego zabiegu. Badanie posiadało również pewne ograniczenia, gdyż według uczestników kształt przewodu słuchowego zewnętrznego był zbyt „zwężający” z powodu twardości materiałów użytych do jego wykonania. Brak możliwości przemieszczania w obrębie chrzęstnej części przewodu również sprawiał pewne trudności przy manipulowaniu narzędziami. Czynność wykonywana podczas symulacji jest tylko jedną z wielu potrzebnych w TEES. Krzywa uczenia obejmuje natomiast wiele czynności składających się na zabieg. Naukowcy pracują na tym, aby nowsze wersje symulatora TEES posiadały łańcuch kosteczek słuchowych oraz okienko owalne i mogły być zaprojektowane do rekonstrukcji kosteczek słuchowych lub chirurgii strzemiączka [32].

Kolejnym problemem, w którego rozwiązaniu może pomóc model stworzony metodą druku 3D, jest trening umieszczania protezy tchawiczo-przełykowej (TEP). TEP umożliwia generowanie głosu po całkowitej laryngektomii $[33,34,35,36,37,38]$. Trening zadań operacyjnych na symulatorach ma na celu poprawę umiejętności technicznych i bezpieczeństwa pacjentów [39, 40,41]. Rozwój druku 3D umożliwia zastosowanie tanich modeli do uzupełnienia takiego treningu $[42,43$, $44,45]$. Symulator został zaprojektowany za pomoca Fusion360 CAD (Autodesk, San Rafael, Kalifornia). Komponenty wydrukowano w technologii 3D przy użyciu drukarki za pomocą kwasu polimlekowego (PLA), a tkanki kałamarnic symulowały wspólną ścianę tchawiczo-przełykową [46]. W badaniu brało udział 10 rezydentów ( $5 \mathrm{z}$ mniejszym oraz $5 \mathrm{z}$ większym doświadczeniem), którym najpierw przedstawiono film instruktażowy dotyczący umieszczenia TEP z objaśnieniami eksperta na temat każdego kroku. Uczestnicy wypełniali ankietę przed i po symulacji. Zdaniem wszystkich rezydentów umiejętności zdobyte podczas symulacji będą przydatne w trakcie prawdziwej operacji. Szczególnie duże korzyści z symulacji odnieśli młodsi rezydenci. Elementy wydrukowane w technologii 3D nie uległy uszkodzeniu podczas powtarzanych symulacji, a użycie tkanek kałamarnic dało bardzo realistyczne sprzężenie zwrotne dotykowe, podobne do błony śluzowej przełyku bez podwyższania kosztów. Dodatkową zaletą jest precyzja modeli z możliwością osiągnięcia rozdzielczości do 20 mikrometrów [46]. Podsumowując, trójwymiarowe symulatory TEP dają możliwość treningu tej skomplikowanej procedury. Dzięki niskim kosztom ich produkcji oraz wysokiej jakości wykonania mogą być wykorzystywane na szeroką skalę, co znacznie przyspieszy szkolenie rezydentów i zwiększy ich umiejętności na sali operacyjnej.

Endoskopowa chirurgia zatok, ze względu na swą złożoność i zmienność anatomiczną oraz ryzyko poważnych powikłań, jest dużym wyzwaniem operacyjnym. Udowodniono skuteczność modeli symulacyjnych 
a training and educational tool in sinus operations as well as in training for rhinologic operations [47]. Three-dimensional models are used in teaching endoscopic sinus surgery (ESS) as well. The study used a printed 3D model that simulated bone structures and soft tissues. Residents and rhinologists performed, among others, antrostomy and removal of the frontal recess on the simulator. The use of simulators has been highly rated in terms of acquiring basic skills in endoscopy [48,49]. Sander et al. described the education of patients with paranasal sinus diseases. For this purpose, they created a model of paranasal sinuses, which was printed in the advanced 3D polyjet method to develop a precise, anatomically faithful replica of the sinuses. The educational 3D model is an effective tool for otolaryngologists to educate their patients by explaining the patient's anatomy, medical condition, and treatment options [50].

\section{$3 D$ printing in reconstructions}

To repair defects and correct the nose and nasal cavity, 3D printing can be used. In the case of nasal septum perforation, on the basis of CT scans 3D templates of the exact shape of the perforation can be printed. In patients with an irregular nasal bone contour, forms obtained thanks to 3D printing can be used and, with the help of silicone injected into them, a specific implant can be obtained for rhinoplasty [51].

Microtia is a rare congenital defect which consists in the deformation of one earlobe and hearing impediments, while the other earlobe usually develops normally. Earlobes are hard to reproduce by standard methods due to their complex structure, which is why $3 \mathrm{D}$ printing seems promising in this field. Chen et al. conducted their study on 6 children with one-sided microtia. Thanks to the presence of one proper earlobe, a mirror image was created by computer, which then enabled the making of a scaffold by means of $3 \mathrm{D}$ printing for surgical reconstruction of the lacking earlobe. The final shape of the prosthesis was made by a 3D printer from porous polyethylene (MEDPOR, Stryker, Kalamazoo). The microtia ear was removed and a one-stage reconstruction was performed consisting in the formation of a cutaneous fascial lobe on the printed scaffold. In one of the six patients, the reconstruction was not successful due to vascularisation problems. In two patients, a temporary issue of alopecia in the operated area was observed. The creation of such a prosthesis made it possible to reconstruct the deformed lobe during one operation, whereas up till now a series of operations was needed. The use of this method enables recreation of the patient's unique ear morphology and the end effect of the surgery is very aesthetic, and the earlobes look symmetrical. However, this method requires further research and standardisation [52].

Zopf et al. are conducting promising research on laser printing prostheses of polycaprolactone that would contain agents stimulating chondrogenesis [53]. w zakresie umiejętności endoskopowych i treningu procedur operacyjnych. Badania wykazały, że symulator może być przydatny jako narzędzie szkoleniowe i edukacyjne w operacjach zatok oraz w treningu do operacji rynologicznych [47]. Modele 3D wykorzystywane są również $\mathrm{w}$ nauczaniu chirurgii endoskopowej zatok (ESS). W badaniach zastosowano model 3D, który symulował struktury kostne i tkanki miękkie. $\mathrm{Na}$ symulatorze rezydenci i rynolodzy wykonali m.in. antrostomię i usunięcie zachyłka czołowego. Badania wykazały, że symulator może być przydatnym narzędziem szkoleniowym/edukacyjnym w operacjach zatok. Ich stosowanie zostało wysoko ocenione w zakresie nabywania podstawowych umiejętności w endoskopii $[48,49]$.

Sander i wsp. opisali edukację pacjentów z chorobami zatok przynosowych. W tym celu stworzyli model zatok obocznych nosa, który został wydrukowany z użyciem zawansowanej metody 3D polyjet celem opracowania ich dokładnej, wiernej anatomicznie repliki. Wyjaśnienie pacjentowi anatomii, stanu chorobowego i opcji leczenia $\mathrm{z}$ wykorzystaniem edukacyjnego model 3D stanowi skuteczne narzędzie, z którego lekarze laryngolodzy mogą korzystać w celu edukacji chorych [50].

\section{Druk $3 D$ w rekonstrukcjach}

Druk 3D możemy wykorzystać do naprawy defektów i korekcji nosa oraz jamy nosowej. W przypadku perforacji przegrody jamy nosowej na podstawie obrazów tomografii komputerowej możemy wydrukować szablony 3D o dokładnym kształcie perforacji. U pacjentów z nieregularnym konturem kości nosowej można zastosować formy uzyskane dzięki drukowi 3D i za pomocą wstrzykiwanego do nich silikonu uzyskiwać specyficzny implant w celu przeprowadzenia plastyki nosa [51]. Mikrotia jest rzadką wadą wrodzoną, która polega na deformacji małżowiny usznej i niedorozwoju słuchu, przy czym druga małżowina najczęściej wykształca się prawidłowo. Małżowiny uszne są trudne do odtworzenia standardowymi metodami, ze względu na swoją złożoną strukturę, dlatego druk 3D wydaje się obiecujący w tej dziedzinie. Chen i wsp. przeprowadzili swoje badanie u 6 dzieci z jednostronną mikrotią. Dzięki obecności jednej prawidłowej małżowiny stworzono komputerowo jej lustrzane odbicie, które pozwoliło na wykonanie za pomocą druku 3D rusztowania do chirurgicznej rekonstrukcji małżowiny brakującej. Ostateczny kształt protezy został wykonany na drukarce 3D z porowatego polietylenu (MEDPOR, Stryker, Kalamazoo). Usunięto mikrotyczne ucho i przeprowadzano jednoetapową rekonstrukcję polegającą na uformowaniu płata skórno-powięziowego na wydrukowanym rusztowaniu. U jednego $\mathrm{z}$ sześciu pacjentów rekonstrukcja zakończyła się niepowodzeniem z powodu problemów $\mathrm{z}$ unaczynieniem. U dwóch pacjentów zaobserwowano przejściowy problem z łysieniem operowanej okolicy. Stworzenie protezy umożliwiło rekonstrukcję zdeformowanej małżowiny podczas jednego zabiegu, zamiast 
Markstedt et al. developed a bioink which combines the properties of nanofibrillated cellulose (NFC) with the rapid cross-linking capacity of alginate enriched with chondrocytes. This material was used to print in 3D technology an earlobe based on CT and MRI scans. Human chondrocytes bioprinted in nanocellulose-based bioink showed cell viability of $73 \%$ and $86 \%$ after 1 and 7 days of $3 \mathrm{D}$ culturing, respectively. The results show that nanocellulose-based bioink is a promising hydrogel for 3D printing with living cells [54].

Recurrent inflammations of the middle ear, especially those accompanied by cholesteatoma, can result in damage to the ossicular chain. To reconstruct them, ossiculoplasty is performed. The procedure of choice is to try and reconstruct them using the patient's own tissues. Due to the complex structure of auditory ossicles, it seems that $3 \mathrm{D}$ printing is great for producing prostheses of auditory ossicles because using such made implants would significantly shorten and simplify the surgery [55]. Xiong et al. printed 3D porous titanium implants, then they examined their properties such as hardness, elasticity, and durability. The results of their studies indicate that this material, due to its physical properties and inexpensive production costs, would be perfect to produce implants [56]. The research of $\mathrm{Li}$ et al. also brings promising results. They implanted guinea pigs with printed implants filled with collagen containing BMP-2. After 3 months of observation, they found that they were able to induce osteogenesis in this way without changing the implant shape, which proves that this method may be used to reconstruct auditory ossicles. In practice, hearing condition improvement was observed in the operated animals as well [57].

Phillippi et al. used bioprinting technology to create spatial forms, on which they immobilised BMP-2 obtained from muscles taken from mature mice. They proved that in properly selected conditions, the cells differentiated in the osteogenesis line direction and in different ones, in the myogenic line direction [58]. This research shows that in future, it will be possible to use bioprinting to create personalised auditory ossicle implants on biodegradable, porous scaffolds, on which cells will be placed that will differentiate in the direction designed by us, under the influence of cytokines such as BMP-2. Such a prepared implant should be fully bio-integrative, which should significantly reduce the risk of its displacement after reconstruction [58].

Tympanic membrane damage is a frequent complication in chronic otitis or a result of a trauma. Currently, tympanic membrane reconstruction consists in reconstructing it using material obtained from the patient. Most often, it is perichondrium, a thin fragment of cartilage taken from an earlobe or temporal fascia. However, these materials are not perfect due to the tympanic membrane function. Kozin et al. used 3D printing to create an artificial tympanic membrane. They developed tympanic membranes made of a scaffold composed of 8 or 16 fibres printed from polydimethylsiloxane (PDMS), polycaprolactone (PCL) and polylactic acid (PLA). This scaffold printed in 3D technology wykonywanych do tej pory serii operacji. Zastosowanie tej metody umożliwia odtworzenie unikalnej morfologii ucha pacjenta, a końcowy efekt zabiegu cechuje się dużą estetyką i symetrycznym wyglądem obu małżowin usznych. Metoda ta wymaga jednak dalszych badań i standaryzacji [52].

Zopf i wsp. prowadzą obiecujące badania nad laserowym drukiem protez z polikaprolaktonu, zawierających czynniki stymulujące chondrogenezę [53].

Markstedt i wsp. opracowali bioink, który łączy właściwości nanofibrylarnej celulozy (NFC) z szybką zdolnością sieciowania alginianu wzbogaconego chondrocytami. Z tego materiału wydrukowano w technologii 3D małżowinę uszną na podstawie skanów $z$ badań TK i MRI. Ludzkie chondrocyty bioprintowane w opartym na nanocelulozie bioinku wykazywały żywotność komórek odpowiednio $73 \%$ i $86 \%$ po 1 i 7 dniach hodowli 3D. Wyniki pokazują, że oparty na nanocelulozie bioink jest obiecującym hydrożelem do druku 3D z żywymi komórkami [54].

Nawracające stany zapalne ucha środkowego, zwłaszcza przebiegające z perlakiem, mogą doprowadzić do uszkodzenia łańcucha kosteczek słuchowych. W celu ich rekonstrukcji wykonuje się ossikuloplastykę. Postępowaniem $\mathrm{z}$ wyboru jest próba ich rekonstrukcji z tkanek własnych pacjenta. Ze względu na złożoną strukturę kosteczek słuchowych wydaje się, że druk 3D świetnie będzie nadawał się do produkcji ich protez, ponieważ zastosowanie tak wykonanych implantów znacznie skróciłoby i ułatwiło operację [55]. Xiong i wsp. wydrukowali w 3D implanty z porowatego tytanu, a następnie zbadali ich właściwości, tj. twardość, sprężystość i wytrzymałość. Wyniki ich badań wskazują, że materiał ten, ze względu na swoje cechy fizyczne oraz niewysoki koszt produkcji, idealnie nadawałby się do stworzenia implantów [56]. Obiecujące wyniki przynoszą również badania Li i wsp., którzy wszczepili świnkom morskim wydrukowane implanty wypełnione kolagenem zawierającym BMP-2. Po 3 miesiącach obserwacji stwierdzili, że udało im się wyindukować w ten sposób osteogenezę bez zmiany kształtu implantu, co udowadnia, że metoda ta może być stosowana do rekonstrukcji kosteczek słuchowych. W praktyce uzyskano też poprawę stanu słuchu u operowanych zwierząt [57].

Phillippi i wsp. wykorzystali technologię bioprintingu do stworzenia wzorów przestrzennych, na których unieruchomili BMP-2 z mięśni pobranych od dorosłych myszy. Udowodnili, że w odpowiednio dobranych warunkach komórki różnicowały się $\mathrm{w}$ kierunku linii osteogennej, a w innych w kierunku miogennej [58]. Badania te pokazują, że w przyszłości można będzie użyć biodruku do stworzenia spersonalizowanych implantów kosteczek słuchowych na biodegradowalnych, porowatych szkieletach, na których umieści się komórki, które pod wpływem cytokin, takich jak BMP-2 różnicować będą się w zaprojektowanym przez nas kierunku. Tak przygotowany implant powinien być w pełni biointegrowalny, co powinno znacznie zmniejszyć ryzyko zmiany jego położenia po rekonstrukcji [58]. 
was then filled with a composite hydrogel of fibrillated collagen. The thus prepared tympanic membranes were compared with tympanic membranes from fresh human corpses and with temporal fascia from corpses. Their acoustic and mechanical properties were assessed using digital opto-electronic holography (DOEH) and laser Doppler vibrometry (LDV), as well as dynamic mechanical analysis (DMA). It was shown that the tympanic membrane made in the $3 \mathrm{D}$ technique is much more similar to the human tympanic membrane than the temporal fascia. Comparing transplants made of 8 or 16 fibres, minimal differences in DOEH and LDV were found for the tested frequencies. The more fibres there were, the more resistant the transplant was to mechanical strain, which is especially positive in comparison with the temporal fascia, which lost $70 \%$ of its capability to transfer sound wave vibrations during mechanical tests. Although the study was carried out in vitro, it proves that the acoustic and mechanical properties of tympanic membranes printed in 3D technology are better than those of temporal fascia used up-to-date. This gives hope for better results of myringoplasty in the future [59].

Kuo et al. attempted to repair a tympanic membrane by means of 3D bioprint based on images obtained from ear endoscopy. The effectiveness of traditionally performed tympanoplasty, i.e. by transplanting cartilage, largely depends on the surgeon's skills to manually reproduce the shape of the graft matching the defect in the tympanic membrane. Therefore, personalised implants printed in 3D technology, based on images from endoscopy, tailored to the shape of the defect of a given patient might be better than those manually created by a surgeon. A study was conducted in chinchillas, in which scaffolds bioprinted in the 3D technique coated with fibroblasts and epidermal growth factor (EGF) were transplanted to defects in the tympanic membrane. Complete healing of the tympanic membrane was obtained, while preserving good acoustic properties. This method needs further studies, though, it shows the possibilities of using $3 \mathrm{D}$ bioprinting not only in otolaryngology but also in other fields of medicine [60].

Total removal of the larynx still remains a method of choice in treating advanced cancer of this organ. Voice production loss is one of the dominant manifestations of disability after this surgery. There have been attempts to transplant larynx from donors, although regretfully recent reports show that despite the success of the transplanted larynx starting to work, there was a gradual process of its rejection, which ultimately led to the necessity of its removal after 10 years [61]. A transplant of this type always requires long-term use of immunosuppressive drugs and yet it is often not permanent. Another method involves the use of an artificial larynx prosthesis that does not provide all the functions of the organ, e.g. the lack of sound vocalisation, although it allows breathing without a tracheostomy tube and prevents the aspiration of food into the respiratory tract [62]. Three-dimensional models of the larynx are already being created using 3D printing,
Uszkodzenie błony bębenkowej jest częstym powikłaniem przewlekłych zapaleń ucha lub skutkiem urazu. Obecnie jej odbudowa polega na rekonstrukcji przy użyciu materiału pobranego od pacjenta. Najczęściej jest to ochrzęstna, cienki fragment chrząstki pobrany z małżowiny usznej lub powięź mięśnia skroniowego. Materiały te nie są jednak doskonałe, $z$ uwagi na czynność błony bębenkowej. Kozin i wsp. wykorzystali druk 3D do stworzenia sztucznej błony bębenkowej. Wykonali je z rusztowania złożonego z 8 lub 16 włókien wydrukowanych $\mathrm{z}$ polidimetylosiloksanu (PDMS), polikaprolaktonu (PCL) i kwasu polietylenowego (PLA), a następnie wypełnili kompozytowym hydrożelem z kolagenu fibrynowego. Tak przygotowane błony bębenkowe zostały porównane $\mathrm{z}$ błonami pochodzącymi ze świeżych zwłok ludzkich oraz z powięzią skroniową ze zwłok. Oceniano ich właściwości akustyczne i mechaniczne za pomoca cyfrowej holografii optoelektronicznej (DOEH) i wibrometrii laserowej dopplerowskiej (LDV) oraz dynamicznej analizy mechanicznej (DMA). Wykazano, że błona wykonana techniką 3D ma właściwości dużo bardziej zbliżone do ludzkiej błony bębenkowej niż powięź skroniowa. Porównując przeszczepy wykonane z 8 lub 16 włókien, wykazano minimalne różnice w DOEH i LDV dla badanych częstotliwości. Wraz z liczbą włókien rosła jednak oporność na obciążenie mechaniczne przeszczepu, co jest bardzo dobrą informacją w porównaniu z właściwościami powięzi skroniowej, która traciła 70\% zdolności do przenoszenia drgań fali dźwiękowej podczas testów mechanicznych. Mimo iż badanie to przeprowadzono in vitro, udowadnia ono, że właściwości akustyczne i mechaniczne wydrukowanej w technologii 3D błony bębenkowej są lepsze niż stosowanej do tej pory powięzi skroniowej, co pozwala mieć nadzieję na lepsze rezultaty myringoplastyki w przyszłości [59].

Kuo i wsp. podjęli próbę naprawy błony bębenkowej za pomoca biodruku 3D na podstawie obrazów uzyskanych z endoskopii ucha. Skuteczność tympanoplastyki wykonywanej standardową techniką przeszczepu chrząstki zależy w dużej mierze od umiejętności chirurga w ręcznym odtworzeniu kształtu przeszczepu dopasowanego do ubytku w błonie bębenkowej. Dlatego implanty wydrukowane $w$ technologii 3D na podstawie obrazów z endoskopii, spersonalizowane, dopasowane do kształtu ubytku błony danego pacjenta mogą być lepsze, niż te tworzone ręcznie przez chirurga. Badanie przeprowadzono na szynszylach, którym przeszczepiono na ubytki w błonie bębenkowej pokryte fibroblastami i naskórkowym czynnikiem wzrostu (EGF) rusztowania wykonane techniką biodruku 3D, uzyskując całkowite wygojenie błony z zachowaniem dobrych właściwości akustycznych. Metoda ta potrzebuje dalszych badań, ale ukazuje możliwości wykorzystania biodruku 3D nie tylko w otolaryngologii, lecz także w innych dziedzinach medycyny [60].

Całkowite usunięcie krtani wciąż pozostaje metodą $\mathrm{z}$ wyboru w leczeniu zaawansowanego raka tego narządu. Utrata funkcji głosotwórczej jest jednym z do- 
mapping individual tissues, allowing the testing of treatment methods of some diseases of the larynx such as vocal fold paralysis that require laryngoplasty injection [63]. 3D printing allowing the reproduction of individual elements of the larynx is currently in the sphere of research which is primarily aimed at the most accurate representation of individual differences in the construction of patients' larynx, in addition to acquiring precise knowledge on the mechanics of its elements. Although $3 \mathrm{D}$ printing technology has been successively developed over the years, it has not yet been successfully applied in larynx reconstruction. Attempts have been made to create 3D models of laryngeal cartilages based on high-resolution computerized tomography (HRCT). This allowed 3D visualisation of individual laryngeal cartilages and their mutual topographic relations to be obtained [64].

The next stage was to analyse the laryngeal joint mechanics, above of all, those of the cricothyroid joint. This was conducted using HRCT as well and Mimics software to determine changes in the position of the vocal folds caused by larynx movements [65]. Perhaps using 3D printing based on already obtained models of laryngeal cartilages would enable more in-depth analysis of their operation. Subsequent, increasingly more precise models allow better visualisation of the elements that model a larynx, while taking into account their function, and their use as training models at the same time and in the future, also as reconstructive models [66]. A forecast of larynx prototyping using $3 \mathrm{D}$ printing is a study conducted by Reszke et al. using Macrolon 2600 polycarbonate with good biocompatibility and corrosion resistance. Thyroid, cricoid and arytenoid cartilages mapped thanks to MR examination were printed on a $3 \mathrm{D}$ printer. The printed cartilages were promising, although in some cases the precision that would allow reproduction of the smallest details was lacking [67]. 3D printing, provided that appropriate material similar to cartilage properties or cartilage itself is used as part of bioprinting, can be used in the future for larynx reconstruction after a partial laryngectomy. For some time now, autotransplants of tissue fragments taken from the patient in order to reconstruct the indispensable functions of the larynx have been used for these purposes [68].

Another problem is long defects in the trachea caused, among others, by tumour resections or traumas. Currently, such defects are supplied by allografts. However, this is not an ideal method because, as in the case of other organs for transplantation, their number is limited and besides, it requires adaptation of their size to the needs of an individual patient. Much hope is placed in the work on creating a trachea prosthesis in 3D printing technology. To fulfil its task, it would not only need to be a scaffold for the airflow path but also to create a favourable environment for the respiratory epithelium and ensure its vascularisation [69]. To reach this aim, Chang et al. created PCL (polycaprolactone) scaffolds printed in the 3D method, coated with mesenchymal stem cells (MSC) seeded in a fibrin and trans- minujących przejawów kalectwa po tym zabiegu. Podejmowano próby przeszczepiania krtani od dawców, niestety ostatnie doniesienia wskazują, że pomimo sukcesu i podjęcia pracy przez przeszczepioną krtań, stopniowo następował proces jej odrzucania, co prowadziło ostatecznie do konieczności jej usunięcia po 10 latach [61]. Tego typu przeszczep zawsze wymaga długotrwałego stosowania leków immunosupresyjnych, a mimo to często jest nietrwały. Inna metoda polega na zastosowaniu protezy sztucznej krtani, niezapewniającej co prawda wszystkich funkcji narządu (np. brak wokalizacji dźwięków), ale pozwalającej na oddychanie z pominięciem rurki tracheotomijnej oraz zapobiegającej aspiracji pokarmu do dróg oddechowych [62]. Powstają już trójwymiarowe modele krtani z wykorzystaniem druku 3D, odwzorowujące poszczególne tkanki, pozwalające na testowanie metod leczenia niektórych schorzeń krtani, takich jak porażenie fałdów głosowych wymagających ich nastrzyknięcia w laryngoplastyce [63]. Druk 3D pozwalający na odwzorowanie poszczególnych elementów krtani jest obecnie w sferze badań, które mają na celu przede wszystkim jak najdokładniejsze odwzorowanie indywidualnych różnic w budowie krtani pacjentów, a ponadto dokładne poznanie mechaniki jej elementów. Pomimo iż od kilku lat technologia druku 3D jest sukcesywnie rozwijana, nie udało się jej wykorzystać z sukcesem w rekonstrukcji krtani. Podejmowano próby utworzenia modeli 3D chrząstek krtani na podstawie badania HRCT (high-resolution computerized tomography). Uzyskano wizualizację 3D poszczególnych chrząstek krtani oraz ich wzajemnych stosunków topograficznych [64]. Przeprowadzono następnie analizę mechaniki stawów krtani, a przede wszystkim stawu pierścienno-tarczowego także z zastosowaniem badań HRCT oraz oprogramowania Mimics, aby określić zmiany położenia fałdów głosowych pod wpływem ruchów krtani [65]. Być może zastosowanie druku 3D na podstawie już uzyskanych modeli chrząstek krtani pozwoliłoby na bardziej wnikliwą analizę ich działania. Kolejne, coraz dokładniejsze modele pozwalają na lepszą wizualizację elementów modelujących krtań z jednoczesnym uwzględnieniem ich funkcji oraz zastosowanie ich jako modeli szkoleniowych, a w przyszłości także jako elementów rekonstrukcyjnych [66]. Zapowiedzią prototypowania krtani z wykorzystaniem druku 3D jest badanie przeprowadzone przez Reszke i wsp. z wykorzystaniem poliwęglanu Macrolon 2600 o dobrej biokompatybilności oraz odporności na korozję. Odwzorowane dzięki badaniu MR chrząstki krtani: tarczowata, pierścieniowata oraz nalewkowate zostały wydrukowane na drukarce $3 \mathrm{D}$. Ich modele były obiecujące, jednak w niektórych wypadkach brakowało precyzji pozwalającej na odwzorowanie najmniejszych detali [67]. Druk 3D, pod warunkiem zastosowania odpowiedniego materiału zbliżonego właściwościami do chrząstki lub samej chrząstki w ramach bioprintingu, można będzie wykorzystać w przyszłości do rekonstrukcji krtani po częściowej laryngektomii. Od pewnego czasu do tych celów wykorzystywane są autoprzeszczepy fragmentów tkanek pobranych od pacjenta 
planted them in four rabbits. In follow-up tests after 4 and 8 weeks, neither CT scans nor endoscopy indicated transplant failure. The histopathology indicated that the prosthesis integrated with the adjoining trachea without the formation of granulation tissue. Examination under a scanning microscope confirmed the regeneration of cilia with a proper structure and function on the respiratory mucosa, which covered the entire surface of the transplant and did not differ from the mucosa of the remaining parts of the trachea. Chondrocyte regeneration sufficient to maintain airway patency was demonstrated as well. PCL scaffolds manufactured by the 3D printing method are inexpensive and enable the production of individual trachea prostheses. The study only covered a period of 8 weeks after the transplantation, therefore further long-term research is needed to assess trachea regeneration [69]. Works are being continued, and their result is the use of a similar method in a 46-year-old patient with tracheostenosis caused by bronchial tuberculosis. After measuring both the length and width of the trachea based on the patient's CT scan, a constricted model of the narrowed trachea was created to facilitate the preparation of the element required for the transplantation. Polycaprolactone (PCL) was used due to its biocompatibility and biodegradability. By mapping the shape of the tracheal cartilage, an external scaffold was printed from it - a $6 \mathrm{~cm}$ long splint placed around the stenosis to which the tissue of the narrowed trachea was attached in order to provide the desired width. After 3 months of observation, no adverse side effects were found in the patient. Moreover, the patient's breathing capacity and physical condition improved significantly. The use of biodegradable materials and tailored to the individual patient, which the $3 \mathrm{D}$ printing method allows, is very important from the point of view of procedures requiring an unusual approach due to the location of the defect in the respiratory tract, as well as in children, enabling size adjustment and eliminating the need to replace the element during growth of the patient [70]. Another approach to the use of $3 \mathrm{D}$ printing is to prepare ready-made transplants to replace the lacking part of airways after its surgical removal. In a pilot study performed on pigs in 2017, Bhor et al. tested a transplant model made of a polycaprolactone scaffold printed in 3D technology and a layer of extracellular matrix collagen. The transplants were designed based on CT scans of the experiment animals and implanted in the place of an earlier removed fragment of the larynx. The length of the prepared implant included 4 tracheal cartilages and the time of preparation from obtaining the CT scans to sterilising before implantation, was 36 hours. Although the initial results were promising, the longest time of survival was 34 days. The cause that ultimately led to the death of the tested animals was the appearance of granulation tissue, which narrowed the trachea and disabled breathing. Interestingly, the animals who were implanted with a $360^{\circ}$ round closed tube survived longer than those with a $270^{\circ}$ open tube, theoretically more similar to real tracheal cartilage. Therefore, it is not an ideal method because, in the case of transplan- w celu odtworzenia lub zachowania niezbędnych funkcji krtani [68].

Osobnym problemem są długie ubytki tchawicy spowodowane m.in. resekcjami z powodu guzów czy urazami. Obecnie zaopatruje się je za pomocą alloprzeszczepów. Nie jest to jednak metoda idealna, ponieważ tak jak w przypadku innych organów do przeszczepów, ich liczba jest ograniczona, a ponadto wymaga dostosowania ich rozmiarów do potrzeb konkretnego pacjenta. Wiele nadziei pokłada się w pracach nad stworzeniem w technologii druku 3D protezy tchawicy. Aby spełniać swoje zadanie, musi ona nie tylko tworzyć rusztowanie dla drogi przepływu powietrza, ale też sprzyjające środowisko dla nabłonka oddechowego i zapewnić mu unaczynienie [69]. W tym celu Chang i wsp. skonstruowali wydrukowane metodą druku 3D rusztownie z PCL (polikaprolaktonu) pokryte mezenchymalnymi komórkami macierzystymi (MSC) wysianymi w fibrynie i przeszczepili je czterem królikom. W badaniach kontrolnych po 4 i 8 tygodniach w TK i endoskopii nie wykazano zapadania się przeszczepów. W badaniu histopatologicznym wykazano, że proteza zintegrowała się z przylegającą tchawicą bez tworzenia tkanki ziarninowej. Pod mikroskopem skaningowym potwierdzono regenerację rzęsek o prawidłowej budowie i funkcji na błonie śluzowej dróg oddechowych, która pokryła całą powierzchnię przeszczepu i nie różniła się istotnie od błony śluzowej pozostałej części tchawicy. Wykazano również wystarczającą do utrzymania drożności dróg oddechowych regenerację chondrocytów. Wytwarzane metodą druku 3D rusztowania z PCL są tanie i umożliwiają produkcję indywidualnych protez tchawicy. Badanie to obejmowało jedynie okres 8 tygodni po przeszczepie, dlatego konieczne są dalsze, długoterminowe badania oceniające regenerację tchawicy [69]. Prace są kontynuowane, czego wynikiem jest zastosowanie podobnej metody u 46-letniej pacjentki ze zwężeniem tchawicy powstałym w wyniku gruźlicy oskrzeli. Po wykonaniu pomiarów zarówno długości, jak i szerokości tchawicy na podstawie badań TK pacjentki sporządzono model zwężonej tchawicy, aby łatwiej opracować element niezbędny do wszczepu. Zastosowano polikaprolakton (PCL), ze względu na jego biokompatybilność oraz biodegradowalność. Odwzorowując kształt chrząstek tchawicy, wydrukowano z niego zewnętrzne rusztowanie - szynę o długości $6 \mathrm{~cm}$ umieszczoną wokół zwężenia, do którego zamocowano tkankę zwężonej tchawicy, aby nadać jej oczekiwaną szerokość. Po 3 miesiącach obserwacji nie stwierdzono żadnych szkodliwych skutków ubocznych u pacjentki, natomiast znacznie poprawiła się jej wydolność oddechowa oraz kondycja fizyczna. Zastosowanie materiałów biodegradowalnych oraz dopasowanych do indywidualnego pacjenta, na co pozwala metoda druku $3 \mathrm{D}$, jest bardzo istotne z punktu widzenia zabiegów wymagających nietypowego podejścia (ze względu na lokalizację ubytku w drogach oddechowych oraz u dzieci), umożliwia bowiem dopasowanie wielkości oraz eliminuje konieczność ich wymiany w trakcie wzrostu pacjenta [70]. 
ting small fragments covering only a part of a trachea excised from the existing organ, its hypertrophy affecting the adjoining epithelial tissue in vivo is possible, which was found in earlier studies. For larger fragments of the organ, it will likely be necessary to use epithelial culture on the surface of the printed transplant prior to its implantation [71].

\section{SUMMARY}

Using 3D models in the education of physicians is significantly less expensive than practising on human corpses. Simulators of this type can also reduce the problem of obtaining standard preparations.

A great advantage of $3 \mathrm{D}$ printing is the possibility of obtaining individual prostheses. They are "made to measure", which allows them to be adjusted to any patient's anatomical conditions. This creates new treatment opportunities for those patients that require particularly precise, individually tailored implants.

Further expansion of 3D printing technology in the future will contribute to a significant reduction in the costs of treating patients with neoplastic lesions. It will also be an important support in the education of future head and neck surgeons.

\section{CONFLICT OF INTEREST}

The authors state that there is no conflict of interest in connection with the published work.

\section{Author's contribution}

Study design - W. Likus

Data collection - R. Wilk, K..Nechoritis, A. Różycka-Nechoritis, K. Przytuła-Kandzia

Manuscript preparation - K. Nechoritis, A. Różycka-Nechoritis, R. Wilk, W. Likus, W. Gaweł, A. Hudecki

Revised - J. Markowski
Inną możliwością wykorzystania druku 3D jest przygotowanie gotowych przeszczepów zastępujących fragment brakującej części dróg oddechowych po jej chirurgicznym usunięciu. W badaniach pilotażowych na świniach przeprowadzonych w 2017 r. przez Bhora i wsp. testowano model przeszczepu złożonego z drukowanego w technologii 3D z polikaprolaktonu szkieletu oraz warstwy kolagenu macierzy pozakomórkowej. Przeszczepy były projektowane na podstawie badania TK zwierząt doświadczalnych, a następnie wszczepiane w miejsce wcześniej usuniętego fragmentu krtani. Długość przygotowanego wszczepu obejmowała 4 chrząstki tchawicze, a czas jego przygotowania od uzyskania zdjęć TK do sterylizacji przed wszczepieniem wynosił 36 godzin. Początkowe wyniki były obiecujące, niestety najdłuższy czas przeżycia wynosił 34 dni. Przyczyną prowadzącą ostatecznie do śmierci badanych zwierząt było pojawienie się tkanki ziarninowej, która zwężała tchawicę, uniemożliwiając oddychanie. Co ciekawe, dłużej przeżywały zwierzęta, u których zastosowano wszczep w kształcie okrągłej zamkniętej rurki $360^{\circ}$ $\mathrm{w}$ porównaniu z wszczepami z zastosowaniem otwartej rurki $270^{\circ}$, teoretycznie bardziej przypominającej chrząstki tchawicy. Nie jest to więc metoda idealna. W przypadku niewielkich przeszczepów, obejmujących jednie fragment tchawicy wycięty $z$ istniejącego organu, jego przerost przez sąsiednią tkankę nabłonkową in vivo jest możliwy, co zostało stwierdzone w badaniach wcześniejszych. Przy większych fragmentach organu prawdopodobnie będzie konieczne zastosowanie hodowli nabłonka na powierzchni wydrukowanego przeszczepu przed jego wszczepieniem [71].

\section{PODSUMOWANIE}

Wykorzystywanie modeli 3D w edukacji lekarzy jest znacznie tańsze niż ćwiczenia na ludzkich zwłokach. Tego typu symulatory mogą również zmniejszyć problem z pozyskiwaniem standardowych preparatów. Dużą zaletą druku 3D jest możliwość otrzymywania indywidualnych protez. Są one tworzone „na wymiar”, przez co mogą być dopasowane do najróżniejszych warunków anatomicznych pacjenta. Stwarza to nowe szanse leczenia pacjentów wymagających szczególnie precyzyjnych, indywidualnie dopasowanych implantów.

Dalsza ekspansja technologii druku 3D w przyszłości przyczyni się do znacznego obniżenia kosztów leczenia pacjentów dotkniętych zmianami nowotworowymi, a także będzie istotnym wsparciem w nauce przyszłych chirurgów głowy i szyi.

\section{KONFLIKT INTERESÓW}

Autorzy stwierdzają brak konfliktu interesów w związ$\mathrm{ku}$ z publikowaną pracą. 


\section{REFERENCES}

1. Kaye R., Goldstein T., Zeltsman D., Grande D.A., Smith L.P. Three dimensional printing: A review on the utility within medicine and otolaryngology. Int. J. Pediatr. Otorhinolaryngol. 2016; 89: 145-148, 10.1016/j.ijporl.2016.08.007. 2. Zadpoor A.A., Malda J. Additive Manufacturing of Biomaterials, Tissues, and Organs. Ann. Biomed. Eng. 2017; 45(1): 1-11. 10.1007/s10439-0161719 -y.

3. Martelli N., Serrano C., van den Brink H., Pineau J., Prognon P., Borget I., El Batti S. Advantages and disadvantages of 3-dimensional printing in surgery: A systematic review. Surgery 2016; 159(6): 1485-1500, doi: 10.1016/j. surg.2015.12.017.

4. Kim G.B., Lee S., Kim H., Yang D.H., Kim Y.H., Kyung Y.S., Kim C.S., Choi S.H., Kim B.J., Ha

H., Kwon S.U., Kim N. Three-Dimensional Printing: Basic Principles and Applications in Medicine and Radiology. Korean J. Radiol. 2016; 17(2): 182-197, doi: 10.3348/kjr2016.17.2.182

5. Cui X., Boland T., D'Lima D.D., Lotz M.K. Thermal inkjet printing in tissue engineering and regenerative medicine. Recent. Pat. Drug. Deliv. Formul. 2012; 6(2): 149-155, doi: 10.2174/187221112800672949.

6. Jang D., Kim D., Moon J. Influence of fluid physical properties on ink-jet printability. Langmuir. 2009; 25(5): 2629-2635, doi: 10.1021/la900059m.

7. Khan M.S., Fon D., Li X., Tian J., Forsythe J., Garnier G., Shen W. Biosurface engineering through ink jet printing. Colloids Surf. B. Biointerfaces 2010 75(2): 441-447, doi: 10.1016/j.colsurfb.2009.09.032.

8. Christensen K., Xu C., Chai W., Zhang Z., Fu J., Huang Y. Freeform inkjet printing of cellular structures with bifurcations. Biotechnol Bioeng. 2015; 112(5): 1047-1055, doi: 10.1002/bit.25501.

9. Gopinathan J., Noh I. Recent trends in bioinks for 3D printing. Biomater Res 2018; 22: 11, doi: 10.1186/s40824-018-0122-1.

10. Hölzl K., Lin S., Tytgat L., Van Vlierberghe S., Gu L., Ovsianikov A. Bioink properties before, during and after 3D bioprinting. Biofabrication. 2016; 8(3): 032002, doi: 10.1088/1758-5090/8/3/032002.

11. Gu B.K., Choi D.J., Park SJ., Kim M.S., Kang C.M., Kim C.H. 3-dimensional bioprinting for tissue engineering applications. Biomater Res. 2016; 20: 12, doi: 10.1186/s40824-016-0058-2.

12. Murphy S.V., Atala A. 3D bioprinting of tissues and organs. Nat. Biotechnol. 2014; 32(8): 773-785, doi: 10.1038/nbt.2958

13. Datta P., Ozbolat V., Ayan B., Dhawan A., Ozbolat I.T. Bone tissue bioprinting for craniofacial reconstruction. Biotechnol. Bioeng. 2017; 114(11) 2424-2431, doi: 10.1002/bit.26349.

14. Datta P., Ayan B., Ozbolat I.T. Bioprinting for vascular and vascularized tissue biofabrication. Acta Biomater. 2017; 51: 1-20, doi: 10.1016/j. actbio. 2017.01.035.

15. Heller M., Bauer H.K., Goetze E., Gielisch M., Ozbolat I.T., Moncal K.K Rizk E., Seitz H., Gelinsky M., Schröder H.C., Wang X.H., Müller W.E., Al-Nawas B. Materials and scaffolds in medical 3D printing and bioprinting in the context of bone regeneration. Int. J. Comput. Dent. 2016; 19(4): 301-321. 16. Hong N., Yang G.H., Lee J., Kim G.J. 3D bioprinting and its in vivo applications. Biomed. Mater. Res. B. Appl. Biomater. 2018; 106(1): 444-459, doi 10.1002/jbm.b.33826

17. Ozbolat I.T. Bioprinting scale-up tissue and organ constructs for transplantation. Trends Biotechnol. 2015; 33(7): 395-400, doi: 10.1016/j.tibtech.2015.04.005

18. Trachtenberg J.E., Placone J.K., Smith B.T., Piard C.M., Santoro M., Scott D.W., Fisher J.P., Mikos A.M. Effects of Shear Stress Gradients on Ewing Sarcoma Cells Using 3D Printed Scaffolds and Flow Perfusion ACS Biomater. Sci. Eng. 2016; 2(10): pp 1771-1780.

19. Kurenov S.N., Ionita C., Sammons D., Demmy T.L. Three-dimensional printing to facilitate anatomic study, device development, simulation, and planning in thoracic surgery. J. Thorac. Cardiovasc. Surg. 2015; 149(4): 973-979, doi: $10.1016 /$ j.jtcvs.2014.12.059

20. Zheng B., Wang X., Zheng Y., Feng J. 3D-printed model improves clinical assessment of surgeons on anatomy. J. Robot. Surg. 2018: 13(1): 61-67, doi 10.1007/s11701-018-0809-2.

21. Werz S.M., Zeichner S.J., Berg B.I., Zeilhofer H.F., Thieringer F. 3D Printed Surgical Simulation Models as educational tool by maxillofacial surgeons. Eur. J. Dent. Educ. 2018: 22(3): e500-e505,

doi: $10.1111 /$ eje. 12332

22. Da Cruz M.J., Francis H.W. Face and content validation of a novel threedimensional printed temporal bone for surgical skills development. J. Laryngol. Otol. 2015; 129(Suppl 3): S23-29, doi: 10.1017/S0022215115001346.

23. Barber S.R., Kozin E.D., Dedmon M., Lin B.M., Lee K., Sinha S., Black N., Remenschneider A.K., Lee D.J. 3D-printed pediatric endoscopic ear surgery simulator for surgical training. Int. J. Pediatr. Otorhinolaryngol. 2016; 90 113-118, doi: 10.1016/j.ijporl.2016.08.027.

24. Sander I.M., Liepert T.T., Doney E.L., Leevy W.M., Liepert D.R. Patient education for endoscopic sinus surgery: preliminary experience using 3D-printed clinical imaging data. J. Funct. Biomater. 2017; 8(2): E13, doi: 10.3390 jfb 8020013 .
25. Maciejewski A., Krakowczyk Ł., Szymczyk C., Wierzgoń J., Grajek M., Dobrut M., Szumniak R., Ulczok R., Giebel S., Bajor G., Półtorak S. The First Immediate Face Transplant in the World. Ann Surg. 2016; 263(3): e36-39, doi: 10.1097/SLA.0000000000001597.

26. http://www.rynekzdrowia.pl/Uslugi-medyczne/Przeprowadzili-symulacjeoperacji-glowy-na-fantomie-z-drukarki-3D,151673,8.html [dostęp: 6.05.2018]. 27. Monfared A., Mitteramskogler G., Gruber S., Salisbury J.K. Jr, Stampfl J., Blevins N.H. High-fidelity, inexpensive surgical middle ear simulator. Otol. Neurotol. 2012; 33(9): 1573-1577, doi: 10.1097/MAO.0b013e31826dbca5.

28. Morris D., Sewell C., Barbagli F., Salisbury K., Blevins N.H., Girod S. Visuo-haptic simulation of bone surgery for training and evaluation. IEEE Comput. Graph. Appl. 2006; 26(6): 48-57, doi: 10.1109/mcg.2006.140.

29. Hochman J.B., Rhodes C., Wong D., Kraut J., Pisa J., Unger B. Comparison of cadaveric and isomorphic three-dimensional printed models in temporal bone education. Laryngoscope 2015; 125(10): 2353-2357, doi: 10.1002/lary. 24919. 30. Rose A.S., Kimbell J.S., Webster C.E., Harrysson O.L., Formeister E.J., Buchman C.A. Multi-material 3D Models for Temporal Bone Surgical Simulation. Ann. Otol. Rhinol. Laryngol. 2015; 124(7): 528-536, doi: 10.1177/0003489415570937.

31. Mick P.T., Arnoldner C., Mainprize J.G., Symons S.P., Chen J.M. Face validity study of an artificial temporal bone for simulation surgery. Otol. Neurotol. 2013; 34(7): 1305-1310, doi: 10.1097/MAO.0b013e3182937af6.

32. Nagendran M., Toon C.D., Davidson B.R., and Gurusamy K.S. Laparoscopic surgical box model training for surgical trainees with no prior laparoscopic experience. Cochrane Database Syst. Rev. 2014; 17(1): CD010479, doi: 10.1002/14651858.CD010479.pub2.

33. Singer M.I., Blom E.D. An endoscopic technique for restoration of voice after laryngec-tomy. Ann. Otol. Rhinol. Laryngol. 1980; 89(6 Pt 1): 529-533, doi: $10.1177 / 000348948008900608$.

34. Singer M.I., Blom E.D., Hamaker R.C. Further experience with voice restoration after total laryngectomy. Ann. Otol. Rhinol. Laryngol. 1981; 90: 498-502.

35. Deschler D.G., Bunting G.W., Lin D.T., Emerick K., Rocco J. Evaluation of voice prosthesis placement at the time of primary tracheoesophageal puncture with total laryngectomy. Laryngoscope 2009; 119(7): 1353-1357, doi: 10.1002/ lary. 20490

36. Divi V., Lin D.T., Emerick K., Rocco J. , Deschler D.G. Primary TEP placement in patients with laryngopharyngeal free tissue reconstruction and salivary bypass tube placement. Otolaryngol. Head Neck Surg. 2011; 144(3): 474-476, doi: 10.1177/0194599810391960.

37. Sethi R.K., Kozin E.D., Lam A.C., Emerick K.S.' Deschler D.G. Primary tracheoesophageal puncture with supraclavicular artery island flap after total laryngectomy or laryngopharyngectomy. Otolaryngol. Head Neck Surg. 2014; 151(3): 421-423, doi: 10.1177/0194599814539443.

38. Deschler D.G., Emerick K.S., Lin D.T., Bunting G.W. Simplified technique of tracheoesophageal prosthesis placement at the time of secondary tracheoesophageal puncture (TEP). Laryngoscope 2011; 121(9):1855-1859, doi: 10.1002/lary.21910.

39. Akhtar K., Sugand K., Sperrin M., Cobb J., Standfield N., Gupte C. Training safer orthopedic surgeons. Construct Validation of a Virtual-Reality Simulator for Hip Fracture Surgery. Acta Orthop. 2015: 86(5): 616-621, doi: 10.3109/17453674.2015.1041083.

40. Reznick R.K., MacRae H. Teaching surgical skills-changes in the wind. N Engl. J. Med. 2006; 355: 2664-2669, doi: 10.1056/NEJMra054785. 41. Barnes R.W. Surgical handicraft: teaching and learning surgical skills. Am. J. Surg. 1987; 153(5): 422-427, doi: 10.1016/0002-9610(87)90783-5.

42. Rose A.S., Webster C.E., Harrysson O.L.A., Formeister E.J., Rawal R.B., Iseli C.E. Pre-operative simulation of pediatric mastoid surgery with 3D-printed temporal bone models. Int. J. Pediatr. Otorhinolaryngol. 2015; 79(5): 740-744, doi: 10.1016/j.ijporl.2015.03.004.

43. Chang D.R. Lin R.P., Bowe S., Bunegin L., Weitzel E.K., McMains K.C., Willson T., Chen P.G. Fabrication and validation of a low-cost, medium-fidelity silicone injection molded endoscopic sinus surgery simulation model. Laryngoscope 2017; 127(4): 781-786, doi: 10.1002/lary.26370.

44. Dedmon M.M., Paddle P.M., Phillips J., Kobayashi L., Franco R.A., Song P.C. Development and validation of a high-fidelity porcine laryngeal surgical simulator. Otolaryngol. Head Neck Surg. 2015; 153(3): 420-426, doi: 10.1177/0194599815590118.

45. Dedmon M.M., Kozin E.D., Lee D.J. Development of a temporal bone model for transcanal endoscopic ear surgery. Otolaryngol. Head Neck Surg. 2015; 153(4): 613-615, doi: 10.1177/0194599815593738.

46. Barber S.R., Kozin E.D., Naunheim M.R., Sethi R., Remenschneider A.K., Deschler D.G. 3D-printed tracheoesophageal puncture and prosthesis placement simulator. 39(1): 37-40, doi: 10.1016/j.amjoto.2017.08.001.

47. Tai B.L., Wang A.C., Joseph J.R., Wang P.I., Sullivan S.E., McKean E.L., Shih A.J., Rooney D.M. A physical simulator for endoscopic endonasal drilling techniques: technical note. J. Neurosurg. 2016; 124(3): 811-816, doi: 10.3171/2015.3.JNS1552 
48. Hsieh T.Y., Cervenka B., Dedhia R., Strong E.B., Steele T. Assessment of a Patient-Specific, 3-Dimensionally Printed Endoscopic Sinus and Skull Base Surgical Model. JAMA Otolaryngol. Head Neck Surg. 2018; 144(7): 574-579, doi: 10.1001/jamaoto.2018.0473.

49. Alrasheed A.S., Nguyen L.H.P., Mongeau L., Funnell W.R.J., Tewfik M.A. Development and validation of a 3D-printed model of the ostiomeatal complex and frontal sinus for endoscopic sinus surgery training. Int. Forum Allergy Rhinol. 2017; 7(8): 837-841.

50. Sander I.M., McGoldrick M.T., Helms M.N., Betts A., van Avermaete A. Owers E., Doney E., Liepert T., Niebur G., Liepert D., Leevy W.M. Three-dimensional printing of X-ray computed tomography datasets with multiple materials using open-source data processing. Anat. Sci. Educ. 2017; 10(4): 383-391, doi: 10.1002/ase.1682.

51. Unkovskiy A., Spintzyk S., Brom J., Huettig F., Keutel C. Direct 3D printing of silicone facial prostheses: A preliminary experience in digital workflow. J. Prosthet. Dent. 2018; 120(2): 303-308, doi: 10.1016/j.prosdent.2017.11.007.

52. Chen H.Y., Ng L.S., Chang C.S., Lu T.C., Chen N.H., Chen Z.C. Pursuing Mirror Image Reconstruction in Unilateral Microtia: Customizing Auricular Framework by Application of Three-Dimensional Imaging and Three-Dimensional Printing. Plast. Reconstr. Surg. 2017; 139(6): 1433-1443, doi: 10.1097/ PRS.0000000000003374.

53. Zopf D.A., Mitsak A.G., Flanagan C.L., Wheeler M., Green G.E., Hollister S.J. Computer aided-designed, 3-dimensionally printed porous tissue bioscaffolds for craniofacial soft tissue reconstruction. Otolaryngol. Head Neck Surg. 2015; 152(1): 57-62, doi: 10.1177/0194599814552065.

54. Markstedt K., Mantas A., Tournier I., Martínez Ávila H., Hägg D., Gatenholm P. 3D Bioprinting Human Chondrocytes with Nanocellulose-Alginate Bioink for Cartilage Tissue Engineering Applications. Biomacromolecules 2015; 16(5): 1489-1496, doi: 10.1021 /acs biomac. 5 b00188.

55. Danti S., D'Alessandro D., Pietrabissa A., Petrini M., Berrettini S. Development of tissue-engineered substitutes of the ear ossicles: PORP-shaped poly(propylene fumarate)-based scaffolds cultured with human mesenchyma stromal cells. J. Biomed. Mater Res. A. 2009; 92(4): 1343-1356, doi: 10.1002 jbm.a.32447. doi: 10.1002/jbm.a.32447.

56. Xiong Y., Chen P., Sun J. Studies on personalized porous titanium implant fabricated using three-dimensional printing forming technique. Sheng $\mathrm{Wu} \mathrm{Y}$ Xue Gong Cheng Xue Za Zhi 2012; 29(2): 247-250

57. Li X.S., Sun J.J., Jiang W., Liu X. Effect on cochlea function by tissueengineering osside prosthets containing controlled release bone morphogenetic protein 2 transplanted into acoustic build in guinea pig. Chin. J. Otorhinolaryngol. Zhonghua Er Bi Yan Hou Tou Jing Wai Ke Za Zhi 2009; 44(6): 490-493.

58. Phillippi J.A., Miller E., Weiss L., Huard J., Waggoner A., Campbell P. Microenvironments engineered by inkjet bioprinting spatially direct adult stem cells toward muscle- and bone-like subpopulations. Stem Cells. 2008; 26(1): 127-134, doi: 10.1634/stemcells.2007-0520.

59. Kozin E.D., Black N.L., Cheng J.T., Cotler M.J., McKenna M.J., Lee D.J., Lewis J.A., Rosowski J.J., Remenschneider A.K. Design, fabrication, and in vitro testing of novel three-dimensionally printed tympanic membrane grafts. Hear Res. 2016; 340: 191-203, doi: 10.1016/j.heares.2016.03.005.

60. Kuo C.Y., Wilson E., Fuson A., Gandhi N., Monfaredi R., Jenkins A., Romero M., Santoro M., Fisher J.P., Cleary K., Reilly B. Repair of Tympanic Membrane Perforations with Customized Bioprinted Ear Grafts Using Chinchilla Models. Tissue Eng Part A. 2018; 24(5-6): 527-535, doi: 10.1089/ten. TEA.2017.0246.

61. Lorenz R.R., Strome M. Total laryngeal transplant explanted: 14 years of lessons learned. Otolaryngol. Head Neck Surg. 2014; 150(4): 509-511, doi: $10.1177 / 0194599813519748$.

62. Debry C., Dupret-Bories A., Vrana N.E., Hemar P., Lavalle P., Schultz P. Laryngeal replacement with an artificial larynx after total laryngectomy: the possibility of restoring larynx functionality in the future. Head Neck. 2014; 36(11): 1669-1673, doi: 10.1002/hed.23621.

63. Hamdan A.L., Haddad G., Haydar A., Hamade R. The 3D Printing of the Paralyzed Vocal Fold: Added Value in Injection Laryngoplasty. J. Voice. 2018; 32(4): 499-501, doi: 10.1016/j.jvoice.2017.07.011

64. Storck C., Gugatschka M., Friedrich G., Sorantin E., Ebner F., Fischer C., Wolfensberger M., Juergens P. Developing a 3D model of the laryngeal cartilages using HRCT data and MIMICS's segmentation software. Logopedics Phoniatrics Vocology. 2010; 35(1): 19-23, doi: 10.3109/14015430903552378. 65. Storck C., Gehrer R., Fischer C., Wolfensberger M., Honegger F., Friedrich G., Gugatschka M. The role of the cricothyroid joint anatomy in cricothyroid approximation surgery. J. Voice. 2011; 25(5): 632-637, doi: 10.1016/j.jvoice. 2010.06 .001

66. Zhang Y., Shi T. The research of laryngeal joints to reconstruction and modeling. Biomed. Mater. Eng. 2014; 24(6): 2627-2634, doi: 10.3233/BME141079.

67. Reszke M., Środulska M., Paluch J., Jasik K., Okła H., Gabor J, Łężniak M., Swinarew B., Swinarew A. Próba rekonstrukcji krtani przy użyciu technik prototypowania 3D z wykorzystaniem poliwęglanu Makrolon 2600. Przetwórstwo tworzyw 2015; 6: 487-492.

68. Jurek-Matusiak O., Wójtowicz P., Szafarowski T, Krzeski A. Vertical partial frontolateral laryngectomy with simultaneous pedunculated sternothyroid muscle flap reconstruction of the vocal fold - surgical procedure and treatment outcomes. Otolaryngol. Pol. 2018; 72(1): 23-29, doi: 10.5604/01.3001.0011.5938

69. Chang J.W., Park S.A., Park J.K, Choi J.W., Kim Y. S, Shin Y. S., Kim C.H. Tissue-engineered tracheal reconstruction using three-dimensionally printed artificial tracheal graft: preliminary report. Artif. Organs. 2014; 38(6): E95-E105, doi: 10.1111/aor.12310

70. Huang L., Wang L., He J., Zhao J., Zhong D., Yang G., Guo T., Yan X., Zhang L., Li D., Cao T., Li X. Tracheal suspension by Using 3-dimentional printed personalized scaffold in patient with tracheomalacia. J. Thorac. Dis. 2016; 8(11): 3323-3328, doi: 10.21037/jtd.2016.10.53.

71. Bhora F.Y., Lewis E.E., Rehmani S.S., Ayub A., Raad W., Al-Ayoubi A.M., Lebovics R.S. Circumferential Three dimentional - Printed Tracheal grafts: Research Model feasibility and early results. Ann. Thorac. Surg. 2017; 104(3): 958-963, doi: 10.1016/j.athoracsur.2017.03.064. 